\title{
ОСОБЕННОСТИ ГЛУБИННОГО СТРОЕНИЯ ЗОНЫ ТРЕЩИННЫХ ТОЛБАЧИНСКИХ ИЗВЕРЖЕНИЙ (КАМЧАТКА, КЛЮЧЕВСКАЯ ГРУППА ВУЛКАНОВ) ПО КОМПЛЕКСУ ГЕОЛОГО-ГЕОФИЗИЧЕСКИХ ДАННЫХ
}

\author{
(C) 2018 г. Ю.А. Кугаенко ${ }^{1, *}$, В.А. Салтыков ${ }^{1}$, А.В. Горбатиков ${ }^{2}$, М.Ю. Степанова ${ }^{2}$ \\ ${ }^{1}$ Камчатский филиал Федерального исследовательского центра “Единая геофизическая служба РАН”, \\ г. Петропавловск-Камчатский \\ ${ }^{2}$ Институт физики Земли им. О.Ю. Шмидта РАН, г. Москва \\ *E-mail: ku@emsd.ru \\ Поступила в редакцию 21.03.2017 г.
}

\begin{abstract}
С использованием метода низкочастотного микросейсмического зондирования исследуется конфигурация магматической питающей системы Толбачинского Дола - региональной зоны ареального базальтового вулканизма в южной части Ключевской группы вулканов на Камчатке. Для получения исходных данных в 2010-2015 гг. проведена пошаговая регистрация фонового микросейсмического поля на детально размеченном полигоне, включающем зоны трещинных извержений 1975-1976 гг. и 2012-2013 гг., а также частично постройку вулкана Плоский Толбачик. Построены глубинные разрезы, отражающие распределения относительных скоростей поперечных сейсмических волн в земной коре. Для большей достоверности интерпретации выявленных глубинных аномалий привлечены результаты независимых геолого-геофизических исследований. Выявленные низкоскоростные неоднородности обнаруживают тесную связь с проявлениями современного вулканизма. Показано, что питающая система Толбачинского Дола пространственно неоднородна и объединяет субвертикальные и латеральные магмоводы, близкорасположенные подводящие каналы и малоглубинные магматические камеры. Обнаружена долгоживущая локальная транскоровая зона магмопроводимости, и выявлены закономерности в глубинном строении питающих систем трещинных извержений. Конфигурация выявленных субвертикальных магмоводов допускает возможность подъема базальтов к поверхности разными путями, что объясняет, в частности, контрастный состав магм в ходе единого извержения. Таким образом, по инструментальным данным показано, что магматическая питающая система Толбачинского Дола имеет ряд особенностей и является значительно более сложной, чем в настоящее время принято считать для полей ареального вулканизма.
\end{abstract}

Ключевые слова: метод низкочастотного микросейсмического зондирования, микросейсмы, вулкан, глубинное строение, магматическая питающая система, Толбачинский Дол, Камчатка

DOI: $10.7868 / \mathrm{S} 0002333718030055$

\section{ВВЕДЕНИЕ}

В Южной части Ключевской группы вулканов на Камчатке расположена протяженная зона голоценового ареального базальтового вулканизма, наложенная на вулкан Плоский Толбачик (рис. 1). Это район преимущественно трещинных извержений, вдоль которых концентрируются моногенные (одноактные) шлаковые конусы и центры лавовых излияний. В течение последних 2 тыс. лет извержения происходили лишь в пределах южной части ареальной зоны, называемой Толбачинским Долом ${ }^{1}$, который является одним из наиболее ак-

\footnotetext{
${ }^{1}$ В данном исследовании Толбачинским Долом именуется Ю-ЮЗ ветвь Толбачинской региональной зоны шлаковых конусов, или Толбачинской ареальной зоны.
}

тивных вулканических объектов Курило-Камчатского региона [Большое..., 1984; Брайцева и др., 1984; Мелекесцев и др., 2001; Новейший..., 2005; Ермаков В.А., Ермаков А.В., 2006; Churikova et al., 2015a].

Детально задокументированы и хорошо изучены различными методами два последних исторических извержения этого района: Большое трещинное Толбачинское извержение 1975-1976 гг. (БТТИ) и трещинное Толбачинское извержение 2012-2013 гг. (ТТИ). Основные результаты исследований БТТИ обобщены в монографиях

Толбачинский Дол рассматривается как самостоятельное вулканическое образование, активное в настоящее время, - Толбачинское поле ареального вулканизма. 


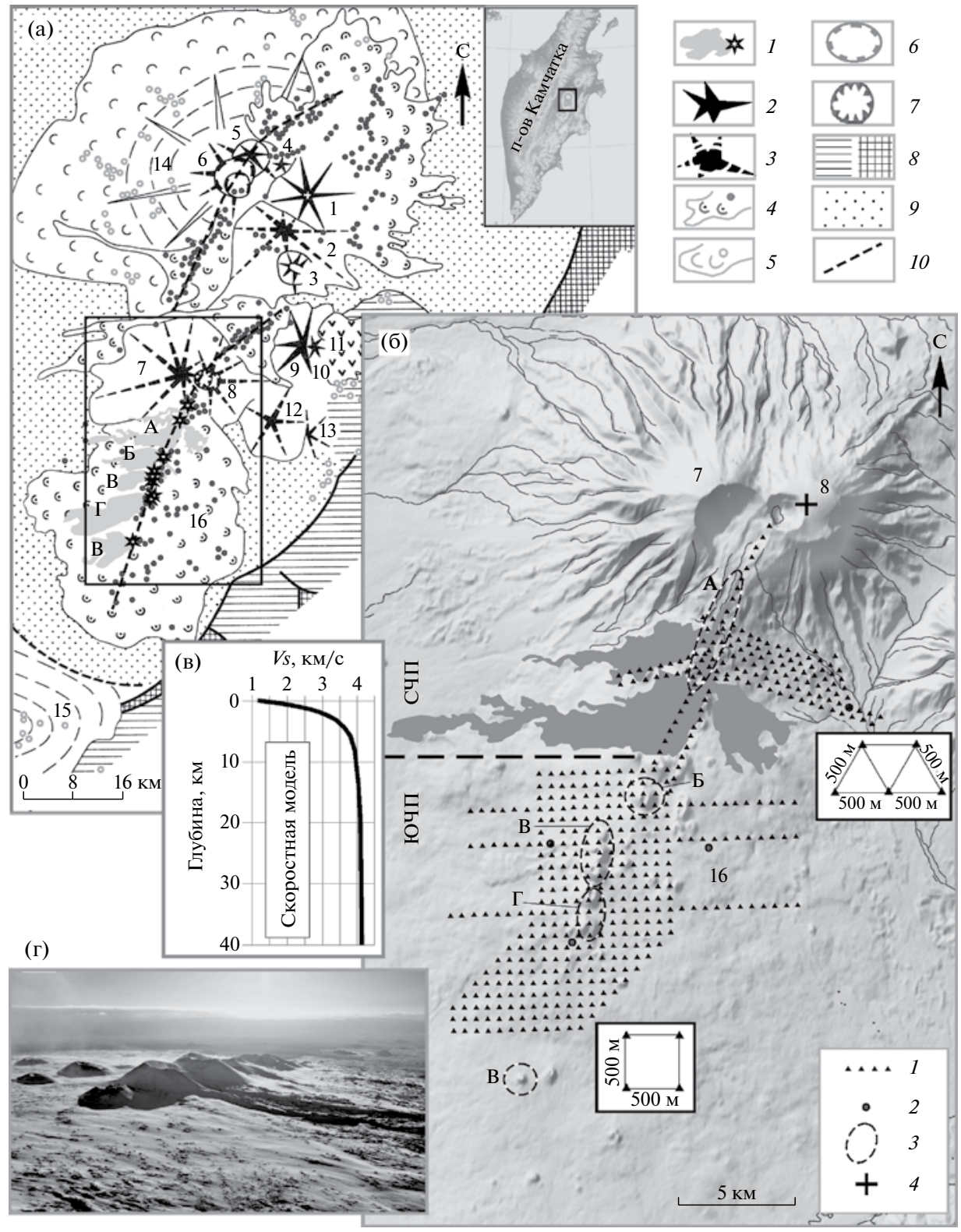

Рис. 1. Ключевская группа вулканов и полигон микросейсмической съемки:

(а) - схематическая карта вулканических образований по работе [Большое..., 1984; Мелекесцев и др., 1991; Федотов и др., 1991] с дополнениями: 1 - эруптивные центры и лавовые потоки ТТИ (А), прорыва Алаид (Б), Северного и Южного прорывов БТТИ (В), прорыва 1004 (Г); 2 - крупные голоценовые стратовулканы; 3 - крупные позднеплейстоцен-голоценовые стратовулканы; 4 - голоценовые шлаковые конусы и их лавовые потоки; 5 - позднеплейстоценовые шлаковые конусы и их лавовые потоки; 6 - голоценовые кальдеры обрушения на вершинах вулканов Плоский Толбачик и Ушковский; 7 - кальдера обрушения на вершине Плоского Толбачика, образовавшаяся в 1975 г. в ходе БТТИ; 8- лавовые плато и дочетвертичные породы складчатого фундамента; 9 - флювиогляциальные и вулканогенно-пролювиальные отложения, аккумулятивные равнины; 10 - осевые линии разломных зон. Номерами обозначены действующие (Д) и потухшие (П) вулканы: 1 - Ключевской (Д), 2 - Камень (П), 3 - Безымянный (Д), 4 - Средний (П), 5 - Крестовский (П), 6 - Ушковский (Д), 7 - Острый Толбачик (П), 8 - Плоский Толбачик (Д), 9 - Овальная Зимина (П), 10 - Острая Зимина (П), 11 - Горный Зуб (реликт плейстоценового вулкана); 12 - Большая Удина (П), 13 - Малая Удина (П), 14 - щитовой вулкан в основании Ушковского и Крестовского вулканов (П); 15 - щитовой вулкан Николка (П), 16 - поле ареального вулканизма Толбачинский Дол (Д). Прямоугольником выделен район, представленный на рис. 1б; (б) - полигон микросейсмической съемки: 1 - реперы микросейсмической съемки; 2 - базовые станции; 3 - зоны трещинных прорывов, обсуждающихся в тексте (соответствуют рис. 1a); 4 - положения древнего кратера вулкана Плоский Толбачик по [Флеров и др., 2015]. Пунктиром отмечена условная граница между южной и северной частями полигона (ЮЧП и СЧП). На вставках проиллюстрировано взаиморасположение реперов микросейсмической съемки в южной и северной части полигона (ЮЧП и СЧП); (в) - скоростная модель VS(H); (г) - цепочка шлаковых конусов в центральной части Толбачинского Дола. 
[Геологические..., 1978; Большое..., 1984]. ТТИ посвящен специальный выпуск журнала (Journal of Volcanology and Geothermal Research. 2015. V. 307), объединивший 17 статей российских и зарубежных ученых. Однако единое мнение по поводу строения магматической питающей системы Толбачинского Дола все еще не сформировалось. С одной стороны, традиционно считается, что зоны трещинных извержений имеют достаточно примитивные системы питания, обеспечивающие быстрое поступление магмы из верхней мантии к поверхности (субвертикальные каналы, иногда осложненные небольшими магматическими камерами) [Nemeth, Kereszturi, 2015]. С другой стороны, в ходе исследований БТТИ было высказано предположение о существовании в коре протяженных сублатеральных магмоводов [Большое..., 1984; Федотов и др., 1991; 2010; 2011; 2014; Флеров и др., 1984; и др.]. Проблема усложняется еще и поступлением на поверхность базальтов контрастного состава: высокомагнезиальных (Mg-базальтов), глиноземистых (Al-базальтов) и их промежуточных разностей, генезис которых в пределах единого центра активности вызывает споры и продолжает активно обсуждаться [Волынец и др., 1978; Ермаков, Геншафт, 1980; Ермаков В.А., Ермаков А.В., 2006; Колосков и др., 2015; 2017; Флеров и др., 2015; Churikova et al., 2015б; Portnyagin et al., 2015; Volynets et al., 2015; и др.].

Таким образом, Толбачинскй Дол, типичное поле ареального базальтового вулканизма, представляет интерес как пример сложно построенных геологических сред, для изучения которых должны привлекаться специализированные инструментальные методы. Для исследования внутреннего строения среды и магматической питающей системы Толбачинского Дола был применен метод микросейсмического зондирования (ММ3) [Горбатиков, 2008б]. В 2010-2015 гг. микросейсмическая съемка была выполнена более чем в 450 точках с шагом 500 м (рис. 1). ММЗ в комплексе с независимыми результатами других геолого-геофизических работ открывает новые возможности для понимания процессов, связанных с особенностями ареальных зон трещинного вулканизма.

\section{ОБЩАЯ ИНФОРМАЦИЯ О РАЙОНЕ ИССЛЕДОВАНИЙ}

Существующие геолого-геоморфологические представления о Толбачинской зоне ареального вулканизма были учтены при планировании микросейсмической съемки.

Толбачинский Дол - южная ветвь Толбачинской региональной зоны шлаковых конусов представляет собой отчетливо выраженную в рельефе вулканическую гряду и имеет форму клина, сужающегося к кратеру Плоского Толбачика. Простирание Толбачинского Дола примерно северо-восточное, длина - 40 км, ширина - около 15 км (рис. 1a). Его главной особенностью является большая концентрация одноактных вулканов в осевой части гряды, в узкой полосе шириной 3-4 км (рис. 1г). В.А. Ермаковым по геологическим данным выделен и описан проходящий здесь глубинный разлом северо-восточного простирания, который рассматривается в качестве главного магмовода, питающего Толбачинский Дол [Ермаков и др., 1984]. В этой же работе впервые говорится о рифтовой природе разломной зоны. Ранее предполагалось, что глубина ее заложения соответствует области перехода между земной корой и верхней мантией (не менее 30-35 км) [Большое ..., 1984]. В работах [Ермаков В.А., Ермаков А.В., 2006; Ермаков и др., 2014] приводится глубина корней разлома, соответствующая средней коре (10-15 км) и предполагается, что плоскость разлома круто падает $\sim$ на юго-восток (угол падения $75-85^{\circ}$ ).

По геофизическим данным установлено, что вся Толбачинская региональная зона ареального вулканизма приурочена к сложнопостроенной структуре опускания глубинных границ земной коры [Балеста, 1977]. Существование разлома подтверждается данными ГСЗ и гравиметрической съемки [Зубин, Таракановский, 1976; Аносов и др., 1978; Балеста и др., 1981]. Глубина кровли кристаллического фундамента составляет под Толбачинским Долом 7-8 км. Голоценовый покров вулканитов вдоль осевой зоны имеет среднюю мощность 200-300 м, максимальную - до 500600 м, он состоит из лавовых потоков, переслаивающихся пирокластикой.

Вулканическая деятельность Толбачинского Дола не прекращается в течение всего голоцена. Раз в несколько столетий здесь происходят трещинные извержения с объемом продуктов более $1 \mathrm{kM}^{3}$. История эруптивной активности этого района изложена в работах [Брайцева и др., 1984; Churikova et al., 2015a] и разделена на два основных этапа. На первом этапе (10-2 тыс. лет назад) на всей площади Толбачинского Дола преобладали многочисленные извержения существенно эффузивного характера, при этом на поверхность поступали исключительно Al-базальты. Второй этап вулканизма (2 тыс. лет назад - настоящее время) имеет ряд отличий: активная область уменьшилась, вулканические проявления сосредоточились в узкой осевой полосе Толбачинского Дола, на поверхность стали поступать базальтовые магмы контрастного состава, в центральной части Дола сформировались крупные шлаковые конусы высотой до 300 м, возрос коэффициент эксплозивности (в ряде случаев - до 30-70\%). 
Еще одна особенность Толбачинского Дола наложение зоны ареального вулканзма на вулкан Плоский Толбачик.

В результате интерпретации сейсмологических и геолого-геофизических исследований БТТИ сформировалось предположение, что Толбачинская зона ареального вулканизма обладает сложной системой магмоводов и разноглубинных промежуточных очагов [Большое..., 1984; Федотов и др., 1991; и др. На момент написания основной монографии, посвященной БТТИ [Большое..., 1984], вопрос о соединении выявленных неоднородностей (промежуточных очагов) остался открытым. Первая модель магматического питания Толбачинского Дола была предложена после БТТИ. Это извержение было представлено Северным и Южным прорывами, расстояние между которыми около 10 км, и сопровождалось образованием на вершине вулкана Плоский Толбачик провальной кальдеры, появление которой предположительно связывалось с оттоком Al-базальтов из-под вулкана в район Южного прорыва. Рои землетрясений, свидетельствовавшие о скрытом внедрении базальтовых даек, вытянулись на 50 км к югу от вулкана Плоский Толбачик, иллюстрируя масштабы происходивших явлений. Модель магматического питания разнесенных вдоль рифта эруптивных центров БТТИ базировалась на гипотезе смешения магматических расплавов и существовании сублатеральных магмоводов, глубины залегания которых оставались дискуссионными [Большое..., 1984].

Представления о сейсмичности Толбачинского Дола базируются на данных Камчатской региональной сети сейсмических станций [Чебров, 2013], которая обеспечивает для этого района уровень надежной регистрации землетрясений Ks = $=4.9$ (по энергетической классификации [Федотов, 1972]). В целом сейсмическая обстановка в районе Толбачинского Дола за период инструментальных наблюдений была спокойной $(\mathrm{Ks}=4-8)$. Исключения составили сейсмические события, связанные с подготовкой БТТИ и началом ТТИ $(\mathrm{Ks}=$ =9-11) [Большое..., 1984; Федотов, 2014; Кугаенко, 2015а; 2015в; Салтыков и др., 2012; Edwards, 2015]. Что касается вулкана Плоский Толбачик, то в ходе БТТИ и подготовки ТТИ он проявлял повышенную сейсмическую активность, которую связывают с одним или двумя долгоживущими периферическими магматическими очагами под стратовулканом [Двигало и др., 1991; Федотов и др., 2011; Ермаков и др., 2014; Belousov et al., 2015; и др.].

\section{МЕТОД ИССЛЕДОВАНИЯ}

Для изучения глубинной структуры земной коры был применён метод микросейсмического зондирования (ММ3) [Горбатиков, 2006; Горбатиков и др., 2008а; 2008б]. Это дифференциальный амплитудный метод, измерения в котором выполняются по принципу “отдельной станцией последовательно в точках сети или профиля”. Вначале ММЗ развивался в значительной степени как эмпирический метод [Горбатиков и др., 2008а; 2008б]. В дальнейшем стали исследоваться теоретические основы ММЗ [Горбатиков, Цуканов, 2011; Цуканов, Горбатиков 2015; Яновская, 2017] и разрабатываться модификации его применения [Жостков и др., 2015]. В данном разделе мы приводим методические основы используемой технологии.

Зондирующий сигнал. В качестве зондирующего сигнала используются фоновые микросейсмические колебания с частотой $\mathrm{f}<1$ Гц. Наиболее признанные механизмы генерации низкочастотных микросейсм - это прямая передача вариаций давления крупных атмосферных вихревых образований непосредственно на поверхность суши либо через водную толщу на дно акваторий с последующим распространением по континенту. Более высокочастотные вариации давления могут порождаться ветровым воздействием на поверхность континента и океана, воздействием прибоя, а также вследствие зарождения внутренних гравитационных волн в слоях океанических вод в районах с протяженным шельфом. ММЗ базируется на ряде предположений, касающихся зондирующего излучения:

- генерация микросейсм происходит в дальней от наблюдателя зоне, регистрируемое микросейсмическое поле является результатом интерференции волн разных типов, оно носит случайный характер;

- в микросейсмическом поле по энергии преобладают волны поверхностного типа; вертикальная компонента микросейсмического поля определяется преимущественным вкладом фундаментальных мод Рэлея (наличие высших мод минимально);

- среда, в которой распространяются микросейсмы, влияет на формирование и распределение их спектральных характеристик; к модели среды не предъявляется требование локальной горизонтальной слоистости, она может иметь вертикальные границы и неоднородности.

Поисковые признаки. В ММЗ используются пространственные вариации спектров мощности микросейсмических сигналов. Информативным параметром является степень искажения спектров исходного микросейсмического поля при его рассеянии на скоростных неоднородностях. Фазовая информация не используется. Форма и глубина залегания неоднородности оценивается исходя из пространственного распределения искажений спектра исходного поля, фиксируемого на земной 
поверхности, и частоты, на которой эти искажения проявляются в максимальной степени.

Родственные методы. Распространёнными в мире методами, родственными ММЗ, являются: 1) модификации метода поверхностно-волновой томографии на основе оценки фазовой части функции Грина по кросс-корреляционной функции [Snieder, 2004; Shapiro, Campillo, 2004; Sabra et al., 2005; Shapiro et al., 2005; Королева и др., 2009]; 2) модификации метода пространственной корреляции ( $S P A C$-методы) [Aki, 1957; Malagnini et al., 1993; Chouet et al., 1998; Ohori et al., 2002; Zhang et al., 2004; Chaves-Garcia et al., 2005; Okada 2006]; 3) модификации метода отношения компонент (H/V-методы) [Nakamura, 1989; Panou et al., 2004; Tanimoto, Alvizuri, 2006; и др.]

Горизонтальное разрешение этих методов составляет величину $2 \div 3 \lambda(\lambda-$ длина волны фундаментальной моды Рэлея, взаимодействующая с неоднородностью). При всем разнообразии технологий реализации (применение сейсмических групп или отдельных точечных измерений) перечисленные подходы объединены тем, что используемая в них модель формирования микросейсмического поля базируется на представлении об обязательной выдержанной локальной слоистости среды.

Численное моделирование. В работе[Горбатиков, Цуканов, 2011] в ходе численного моделирования прямой задачи рассеяния в трехмерной постановке показано, что на поверхности Земли над высокоскоростными неоднородностями (скорости упругих волн в неоднородности выше, чем во вмещающей среде) спектральные амплитуды в определенном частотном диапазоне уменьшаются, а над низкоскоростными (скорости ниже, чем во вмещающей среде) - возрастают. Обнаружено, что при этом существует критическая частота волны Рэлея $f_{c}$, для которой искажения от неоднородности, залегающей на глубине $H$ максимальны по сравнению с искажениями от этой же неоднородности на соседних частотах $f$ наблюдаемого спектра. Частота $f_{c}$ связана с глубиной $H$ и региональной моделью дисперсионной кривой фундаментальной моды волны Рэлея $V_{R}(f)$ соотношением: $H \approx 0.4 V_{R}\left(f_{c}\right) / f_{c}$, что подтверждается модельными расчетами и исследованиями геологических объектов различного масштаба и генезиса. Длина волны $\lambda_{e}=V_{R}\left(f_{c}\right) / f_{c}$, соответствующая $f_{c}$, называется эффективной длиной волны для глубины $H$. Численный коэффициент 0.4 называется коэффициентом глубинной привязки $K$.

Модель формирования амплитудных искажений в трехмерной постановке автоматически учитывает не только перераспределение энергии по вертикали в модах поверхностных волн Рэлея при условии сохранения полного потока энергии, но и весь спектр взаимодействий на границе неоднородностей, включая отражение, обмен и пр. Ограничения на размер включений и их контраст существенно ослаблены. Так, положение центра компактной неоднородности может быть оценено даже если размеры неоднородности составляют четверть длины эффективной волны и менее.

Полученное соотношение для прямой задачи $H \approx 0.4 V_{R}\left(f_{c}\right) / f_{c}$ используется в ММЗ для оценки глубины залегания неизвестной неоднородности (оценки решения обратной задачи). Такая оценка глубины производится из предположения, что в микросейсмическом поле все наблюдаемые спектральные частоты $f$ однозначно связаны с соответствуюшими длинами волн $\lambda=V_{R}(f) / f$, то есть вклад фундаментальных мод Рэлея предполагается подавляющим, и, кроме того, считается, что модель средней региональной дисперсионной кривой $V_{R}(f)$ известна из независимых источников.

Поскольку при использовании ММЗ наличия стабильно выдержанных по всей площади исследования горизонтальных слоев с высоким контрастом скоростей не предполагается (что в природных условиях встречается редко и, как правило, лишь вблизи поверхности), то считается, что высшие моды Рэлея всегда имеют амплитуды меньшие, чем фундаментальная мода. В свою очередь, поверхностная природа источников самого микросейсмического поля еще более усиливает допушение о преобладании фундаментальных мод.

Прямая задача для одиночных тел простой формы. В работе [Горбатиков, Цуканов, 2011] на разработанном комплексе программ проведены расчеты влияния заглубленных включений на пространственное распределение спектра мощности поля поверхностных волн Рэлея. Рассмотрены включения различной формы, размеров, глубины залегания и скоростного контраста по отношению к вмещающей среде, но при этом рассмотрение ограничено случаями с неизменным значением коэффициента Пуассона в самой неоднородности и во вмещающей среде. Показано, что амплитудная реакция не чувствительна к форме скоростного включения, если его размеры не превышают $\lambda / 4$, где $\lambda$ - длина фундаментальной моды волны Рэлея, соответствующая глубине залегания. При этом возможно обнаружить присутствие включения и определить знак его скоростного контраста. В терминах глубин, используя коэффициент глубинной привязки, можно утверждать, что изображения двух неоднородностей со скоростными контрастами одного знака должны сливаться, если расстояние по горизонтали между ними составляет половину глубины их залегания или менее.

Исследование эффекта “сверхразрешения". Основные закономерности формирования сигнала 
в ММЗ, полученные на численной модели, находятся в хорошем соответствии с результатами полевых экспериментов. Однако в ряде натурных экспериментальных наблюдений было обнаружено, что полученные изображения не соответствуют результатам описанной серии численных расчетов. Это относится к возможности раздельного наблюдения двух субвертикальных структур на глубинах, где, в соответствии с расчетами, изображения должны сливаться в одно, то есть, наблюдается “сверхразрешение". Обнаруженное несоответствие между результатами расчетов и экспериментов потребовало проведения дополнительного исследования, в ходе которого было показано, что эффект “сверхразрешения" может наблюдаться, если коэффициент Пуассона материала включения приближается к нулевому значению [Gorbatikov et al., 2013; Цуканов, Горбатиков, 2015]. В природных условиях это может означать наличие во включении развитой микротрещинноватости либо повышенной пористости. К настоящему времени на численных моделях изучены вопросы: 1) о влиянии коэффициента Пуассона неоднородности на ее изображение в микросейсмическом поле; 2) об оценке величины нелинейного эффекта амплитудной реакции в ММЗ в случае двух близкорасположенных заглубленных тел.

Источники ошибок. При оценке глубины включения в ходе решения обратной задачи возможны ошибки. Их источниками являются:

- во-первых, допушения, принятые относительно состава микросейсмического поля. Присутствие высших мод Рэлея, а также объемных волн, падающих почти вертикально снизу, может вносить искажение в результирующую картину; искажение тем большее, чем выше амплитуды неучтенных мод по сравнению с амплитудами фундаментальных мод Рэлея тех же частот;

- во-вторых, поскольку оценка глубины неоднородности не представляет собой процедуру, автоматически сходящуюся к некому решению, то источниками ошибок являются неточности в оценке коэффициента глубинной привязки $K \approx 0.4$ с одной стороны и неточности знания региональной дисперсионной модели $V_{R}(f)$ с другой стороны. Коэффициент привязки является функцией знака и контраста скорости включения по сравнению с вмещающей средой и варьирует неизвестным образом по площади исследования. Эту зависимость, в принципе, можно учитывать на основе расчета [Горбатиков, Цуканов, 2011]. Однако на его основе можно также показать, что если отклонения скоростей во включениях находятся в пределах $\pm 50 \%$ относительно скоростей вмещающей среды, то ошибка оценки глубины включений за счет неучтенных вариаций коэффициента не превысит, соответственно, $\pm 4 \%$. При этом считается, что модель $V_{R}(f)$ известна точно. Поскольку коэффициент и дисперсионная модель входят в формулу мультипликативно, то дополнительная ошибка в оценку глубины вносится за счет неточностей самой дисперсионной модели. На практике, в случаях, когда оценка глубины имеет принципиальное значение, можно произвести процедуру калибровки функции $K V_{R}(f)$ в контрольных точках по независимым данным (например, по бурению). Аналогичная процедура выполняется в промышленных методах МОВ при миграции “времени” в “глубину”. Однако во многих задачах, например, в региональных тектонических исследованиях указанной точности, как правило, достаточно, и вполне можно пользоваться простой оценкой: $K \approx 0.4$.

- в-третьих, заметим, что оценка геометрических границ включений в плане (по горизонтали) производится по ММЗ без ошибок и зависит лишь от полноты “освещения” включения микросейсмическими волнами со всех сторон.

Разрешающая способность ММЗ. Согласно численным экспериментам [Горбатиков, Цуканов, 2011], разрешающая способность метода при восстановлении изображения по горизонтали оценивается как $(0.25 \div 0.3) \lambda$, где $\lambda$ - эффективная зондирующая длина волны. В соответствии с указанной работой, разрешение по вертикали можно оценить как $(0.25 \div 0.3) \lambda$, где $\lambda-$ эффективная длина волны для средней глубины между неоднородностями. Близкую оценку разрешения по вертикали можно также получить по результатам аналитического подхода [Яновская, 2017]. В работе [Горбатиков, Цуканов, 2011] показано, что обнаружить присутствие изолированной малой неоднородности возможно, даже если ее размеры меньше длины волны в 10 и более раз.

Теоретическое обоснование ММЗ. На основе теории поверхностных волн в работе [Яновская, 2017] было получено теоретическое объяснение формирования поисковых признаков, используемых в ММЗ. В этом аналитическом подходе существенными требованиями при постановке задачи являлись: 1) слабая контрастность включений на фоне вмещающей среды и 2) значительные размеры включений по горизонтали (не менее 2-3 длин эффективной волны). Постановка задачи являлась одномерной. Ограничения в постановке накладывались, чтобы свести задачу к перераспределению потока энергии в волне Рэлея исключительно по вертикали, исходя из условия его сохранения. Процессы отражений и обменов на вертикальных границах включений в расчет не принимались.

Положительной стороной использования аналитического подхода ввиду его точности, является эффективная (с точки зрения затрат компьютерного времени) возможность моделирования 
градиентных сред с включениями и возможность исследования механизма и закономерностей перераспределения энергии в волне по вертикали. Значение коэффициента глубинной привязки в аналитическом подходе оценено как 0.3, что близко к оценке коэффициента, полученной в численном моделировании [Горбатиков, Цуканов, 2011] для двумерной постановки.

Микросейсмическая съемка. Методика проведения полевых измерений сводится к накоплению спектра мощности микросейсмического сигнала в течение некоторого времени последовательно от точки к точке вдоль профиля одним или несколькими переносными датчиками. Одновременно регистрируется микросейсмический сигнал на опорной точке в пределах исследуемого полигона. Коррекция на нее выполняется для устранения эффекта нестационарности зондирующего микросейсмического сигнала. В зависимости от поставленной задачи возможно проведение как профильной, так и площадной съемки.

Скоростная модель. ММЗ позволяет построить разрез локальных скоростных пространственных вариаций по отношению к некоторой средней региональной скоростной модели, которая либо берется из независимых источников, либо оценивается независимо от ММЗ с помощью активных или пассивных сейсмологических методов. Степень отклонения от региональной скоростной модели выражается в децибелах и определяется согласно тоновой шкале. Известно, что дисперсионная кривая, рассчитанная по горизонтально слоистой скоростной модели, ведет себя достаточно устойчиво по отношению даже к значительным вариациям скоростей в слоях исходной модели, с чем связана неединственность решения обратной задачи строения на основе измерения дисперсионной картины, что отмечается многими исследователями. Обратим внимание, что ММЗ позволяет получить разрез в параметрах вариаций скоростей по отношению к региональной скоростной модели, но при этом в процедуре ММЗ используется лишь дисперсионная кривая, соответствующая этому скоростному разрезу. Саму скоростную модель разреза можно при этом не определять, но любая выбранная региональная скоростная модель должна обеспечивать именно ту дисперсионную кривую, которая принята в расчет.

Краткое резюме. В заключении к методическому разделу отметим, что оценка решения обратной задачи в ММ3, также как и в большинстве геофизических методов, не единственна. Невозможно восстановить сложный комплекс параметров среды, исходя только из распределения амплитудной реакции неоднородностей на облучение микросейсмическими волнами. Но численное моделирование и аналитический подход позволяют констатировать, что результаты ММЗ вполне могут быть использованы для геологической интерпретации, хотя количественно они могут варьировать. В большом количестве практических случаев оценка неучтенных ошибок решения обратной задачи по глубине показывает, что для геологической интерпретации они не имеют принципиального значения; а в горизонтальное положение объектов ММЗ ошибки не вносит.

В частности, возможность выделять субвертикальные структуры и исследовать объекты с глубинными “корнями” продемонстрирована для грязевых вулканов и кимберлитовых трубок [Собисевич и др., 2008; Горбатиков и др., 2009; Danilov, 2017]. Накапливается опыт исследований магматических аппаратов различных активных вулканических областей: вулканический остров Эль Иерро в Канарском архипелаге [Gorbatikov et al., 2013], вулкан Эльбрус на Кавказе [Рогожин и др., 2016], Авачинский вулкан и Узон-Гейзерная вулкано-тектоническая депрессия на Камчатке [Абкадыров и др., 2014; Кугаенко и др., 2015б]. Первые результаты наших исследований конфигурации "корней" вулканов в центральной части Толбачинского Дола представлены в работе[Кугаенко и др., 2013].

\section{ПОЛУЧЕНИЕ ИСХОДНЫХ ДАННЫХ}

В соответствии с технологией ММЗ для получения исходных данных для исследования магматической системы Толбачинского Дола была проведена микросейсмическая съемка - регистрация фонового микросейсмического поля в заданных точках. Полигон микросейсмической съемки представлен на рис. 1б. Использовались портативные широкополосные цифровые велосиметры Guralp CMG-6TD с частотой дискретизации 100 отсчетов/сек, рабочий частотный диапазон 0.03-25 Гц. Эти приборы обеспечивают надежную регистрацию поверхностных волн длиной до 100 км (при скоростях волн Рэлея до $\sim 4 \mathrm{KM} /$ сек) и глубину зондирования до $\sim 40$ км. Полигон был размечен с помощью цифровых карт на этапе подготовки полевых работ с занесением координат точек наблюдения в портативные GPS-навигаторы. Такой подход обеспечил линейность профилей съемки и равномерность реперов. Шаг съемки составил 500 м. Время регистрации в каждой точке было не меньше трех часов для достижения статистической устойчивости спектра в соответствии с работой [Горбатиков, Степанова, 2008]. Одновременно с проведением пошаговой микросейсмической съемки для компенсации временных вариаций в спектре микросейсм непрерывно работали 2-3 базовые станции, установленные в различных местах полигона. 
Полученные волновые формы подвергались визуальному контролю для исключения участков, на которых присутствовали технические и антропогенные помехи, а также записи локальных и удаленных землетрясений.

В 2010-2012 гг. работы были ориентированы на исследование центрального участка Толбачинского Дола, где сосредоточены наиболее крупные, высотой до 300 м, шлаковые конусы, включая постройки Северного прорыва БТТИ. Эта условно южная часть полигона включает область эквидистантной площадной съемки и три линейных профиля длиной 14-15 км, проведенных в крест магмопроводящей разломной зоне через разновозрастные трещинные прорывы. В конце ноября 2012 г. началось ТТИ, и полевые работы 20132015 гг. сместились в северную часть полигона. Для исследования ТТИ была выполнена регистрация микросейсм вдоль системы параллельных профилей, пересекающих протяженную трещинную зону этого извержения. Летом 2014 г. был пройден профиль до края вершинной кальдеры вулкана Плоский Толбачик.

В ММЗ для построения глубинного изображения используется скоростная модель $V_{R}(f)$. При изучении Толбачинского Дола мы используем данные по скоростному строению среды, полученные ранее при геофизических исследованиях БТТИ [Балеста 1977; Большое..., 1984; Гонтовая и др., 2015]. В наших расчетах применяется скоростная модель $V_{R}(f)$, оцененная по этому сейсмическому разрезу $V_{P}(H)$ и соответствующему разрезу $V_{S}(H)$ (рис. 1в), где $V_{P}$ и $V_{S}-$ скорости продольных и поперечных сейсмических волн.

В настоящей публикации авторы не используют записи, которые были получены в августе 2013 г. во время ТТИ (ММ3-профили пересекали эруптивную зону). Такое решение связано с присутствием в записях низкочастотных сигналов локального эндогенного происхождения, так как во время полевых работ в августе 2013 г. шло умеренное извержение стромболианского типа: наблюдалась ритмичная эксплозивно-эффузивная деятельность, на дне кратера плескалось озеро жидкой лавы, охваченной интенсивным движением и бурным отделением летучих. Регистрировалось вулканическое дрожание с максимумом на частоте 1-3 Гц, распространявшееся в область более низких частот, до 0.2-0.3 Гц. Также регистрировались мощные акустические сигналы: воздушные ударные и инфразвуковые волны, сопровождавшие разрушение лавовых пузырей на поверхности лавового озера, со спектральным максимумом в диапазоне частот 0.5-1.5 Гц; квазипериодичность взрывов колебалась от 0.1 Гц до 1.6 Гц [Кугаенко и др., 2013б; Albert et al., 2015]. Отток лавы осуществлялся по системе лавовых труб со скоростью
1-2 м/с, местами происходило выжимание лавы на поверхности ранее образованных лавовых покровов. В этих условиях в ходе микросейсмической съемки в эруптивной зоне были зафиксированы интенсивные низкочастотные колебания с частотой $0.1-0.01$ Гц и ниже, которые, вероятно, были связаны с деформациями поверхности в связи с перемещениями жидкой лавы по системе скрытых лавовых каналов непосредственно под зоной наблюдений. Все перечисленные низкочастотные сигналы, связанные с извержением вулкана (вулканическое дрожание, акустические возмущения, быстрые деформационные процессы), приводят к появлению на ММ3-разрезах ложных аномалий. В настоящее время вопрос о техническом разделении полезных с точки зрения ММЗ сигналов и указанных локальных помех не решен.

Имеющиеся материалы по ММЗ позволяют получить представление об особенностях строения среды на достаточно большой территории, характеризующейся неравномерным проявлением вулканизма (рис. 1б). Полигон позволяет скомпилировать целый ряд протяженных профилей, проходящих через различные вулканические объекты. При этом разрезы, построенные для близко расположенных профилей и хорошо коррелирующие между собой, свидетельствуют о реальности выявленных аномальных структур.

\section{РЕЗУЛЬТАТЫ С ЭЛЕМЕНТАМИ ИНТЕРПРЕТАЦИИ}

Результаты применения ММЗ представлены в виде вертикальных разрезов вдоль профилей. Рисунки выполнены в оттенках серого цвета и отражают скоростные контрасты относительно сглаженной региональной скоростной модели. Зонам с повышенными скоростными свойствами соответствует более темный цвет, а аномалии с пониженными скоростями выделяются светлыми тонами. Для удобства восприятия каждый разрез сопровождается схемой полигона, на которой выделен соответствующий профиль. Некоторые рисунки дополнены геолого-геофизической информацией.

При интерпретации выявленных неоднородностей мы учитывали, что профили прошли через зоны реально существовавших извержений, в ходе которых имел место подъем глубинного вещества к поверхности. Поэтому мы считаем возможным при интерпретации результатов наших построений употреблять термины "магматический очаг”, “магмовод”, “питающий канал извержения”. Обширные относительно низкоскоростные области, приуроченные к элементам изучаемой магматической питающей системы, мы рассматриваем как 
возможные зоны микротрещиноватости и разуплотнения среды. Мозаичные изображения в приповерхностных частях ММ3-разрезов не всегда поддаются интерпретации. Одной из причин может быть сложность локальной гидрогеологической и геокриологической обстановки [Большое ..., 1984; Андреев и др., 2006; Ермаков В.А., Ермаков А.В., 2006; Абрамов, Гиличинский, 2008]. В частности, поверхностный сток в зоне шлаковых конусов практически отсутствует, он дренирован на более глубокие уровни, где не исключаются области аккумуляции воды. Вода может значительно влиять на скоростные свойства среды и искажать результаты ММЗ.

\section{Профили вдоль Толбачинского Дола}

На рис. 2 приводится квази-3D-представление ММ3-разрезов вдоль двух соединяющихся под острым углом профилей: первый соответствует южной границе полигона, второй тянется от юго-западного угла полигона до подножия вулкана Плоский Толбачик. Длина первого участка 6 км, второго - 23 км. В южной части полигона профиль идет по гряде молодых одноактных вулканов - крупнейших шлаковых конусов Толбачинского Дола, включая и Северный прорыв БТТИ. В северной части он проходит примерно в 1 км к востоку от зоны ТТИ. В верхней части рисунка справа представлено оригинальное изображение ММ3-разреза, на котором читатель визуально может выделить низкоскоростные зоны, окрашенные в более светлые тона. Внизу приведено это же изображение, но с нанесенными на него дополнительными элементами, необходимыми для интерпретации и увязки с геологическими данными.

По аналогичной схеме составлен рис. 3. Квази-3D-представление объединяет часть разреза вдоль южной границы полигона (3 км) и длинный профиль (28 км), захватывающий те же крупнейшие конуса в центральной части Дола, затем проходящий вдоль шестикилометровой зоны эруптивных центров ТТИ и поднимающийся на вулкан Плоский Толбачик до кромки кальдеры.

Отметим, что для разрезов, представленных на рис. 2 и рис. 3 , общими являются лишь единичные точки съемки, поэтому результаты расчетов можно рассматривать как независимые. При этом разрезы схожи. Мы считаем, что этот факт очень важен и рассматриваем его как подтверждение реального существования глубинных неоднородностей, которые проявились на этих изображениях. Таким образом, на обоих рисунках выделяются низкоскоростные аномалии:

- крупная воздымающаяся аномалия под центральной частью Дола (зона I), которая может интерпретироваться как транскоровая область магмопроводимости, обеспечивающая поступление к поверхности глубинных Mg-базальтов, наиболее характерных именно для этого участка;

- отходящая от нее в южном направлении, за пределы полигона, на глубине 4-8 км низкоскоростная структура (зона II), которая хорошо проявляется в квази-3D ракурсе и может являться сублатеральным магмоводом, питающим эруптивные центры южной части Толбачинского Дола в соответствии с работой [Большое..., 1984];

- сублатеральная структура (зона III), уходящая в сторону вулкана Плоский Толбачик.

Профиль, изображенный на рис. 2, в северо-восточной части иллюстрирует ярко выраженную аномалию на глубине больше 10 км (зона $\boldsymbol{I V}$ ), заглубляющуюся под вулкан Плоский Толбачик. На рис. 3 отмечен знаком (*) локальный восходящий элемент, который может интерпретироваться как не достигший поверхности питающий канал.

Выявленные аномалии мы сопоставили с некоторыми сформулированными ранее представлениями (гипотезами) об особенностях магматического питания района полигона. Для сравнения на ММ3-разрезы на рис. 2, рис. 3 нанесена петрологическая модель магматического питания БТТИ, базирующаяся на идее смешения базальтов разного состава ${ }^{2}$, поступивших на поверхность в ходе единого извержения, но пришедших из различных пространственно разнесенных источников [Волынец и др., 1978; Флеров и др., 1984; Федотов и др., 1991]. Эта модель предполагает подъем базальтов из глубины к БТТИ по единому каналу (что соответствует зоне I) и латеральные перемещения базальтов из-под Плоского Толбачика к югу, причем на участке между Северным и Южным прорывом БТТИ предполагался малоглубинный магмовод (что соответствует зоне II). В работах С.А. Федотова, посвященных разработке модели магматического питания Ключевской группы вулканов, предполагается, что под вулканом Плоский Толбачик на глубине 15-22 км присутствует слой, по которому базальты могут перемещаться вдоль осевой линии разломной зоны [Федотов и др., $2010 ; 2014$; и др.]. Он изображен штриховкой на рис. 2 , рис. 3 и может быть сопоставлен с аномалиями $\boldsymbol{I I I}$ и $\boldsymbol{I V}$. Таким образом, характер ММЗаномалий согласуется с приведенными модельными представлениями, незначительные отличия наблюдаются лишь в глубине сублатеральных магмоводов.

Участок разреза, проходящего непосредственно через трещинную зону ТТИ, не обладает

\footnotetext{
${ }^{2}$ Пути движения базальтов взяты из работы [Федотов и др., 1991], где представлена схема магматического питания БТТИ, составленная Г. В. Флеровым (с. 273, рис. 180).
} 
(б)

(a)

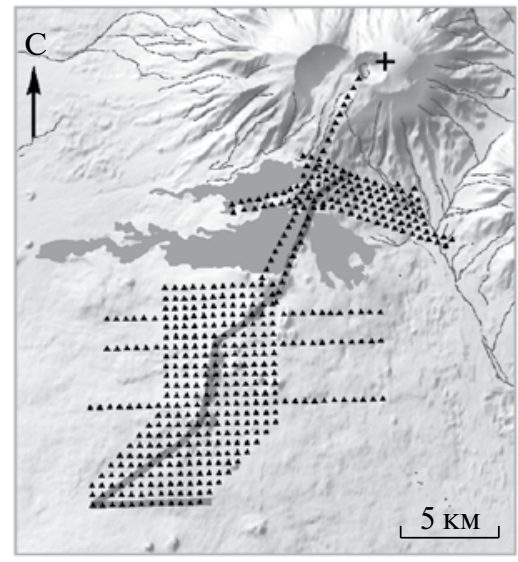

Крупнейшие

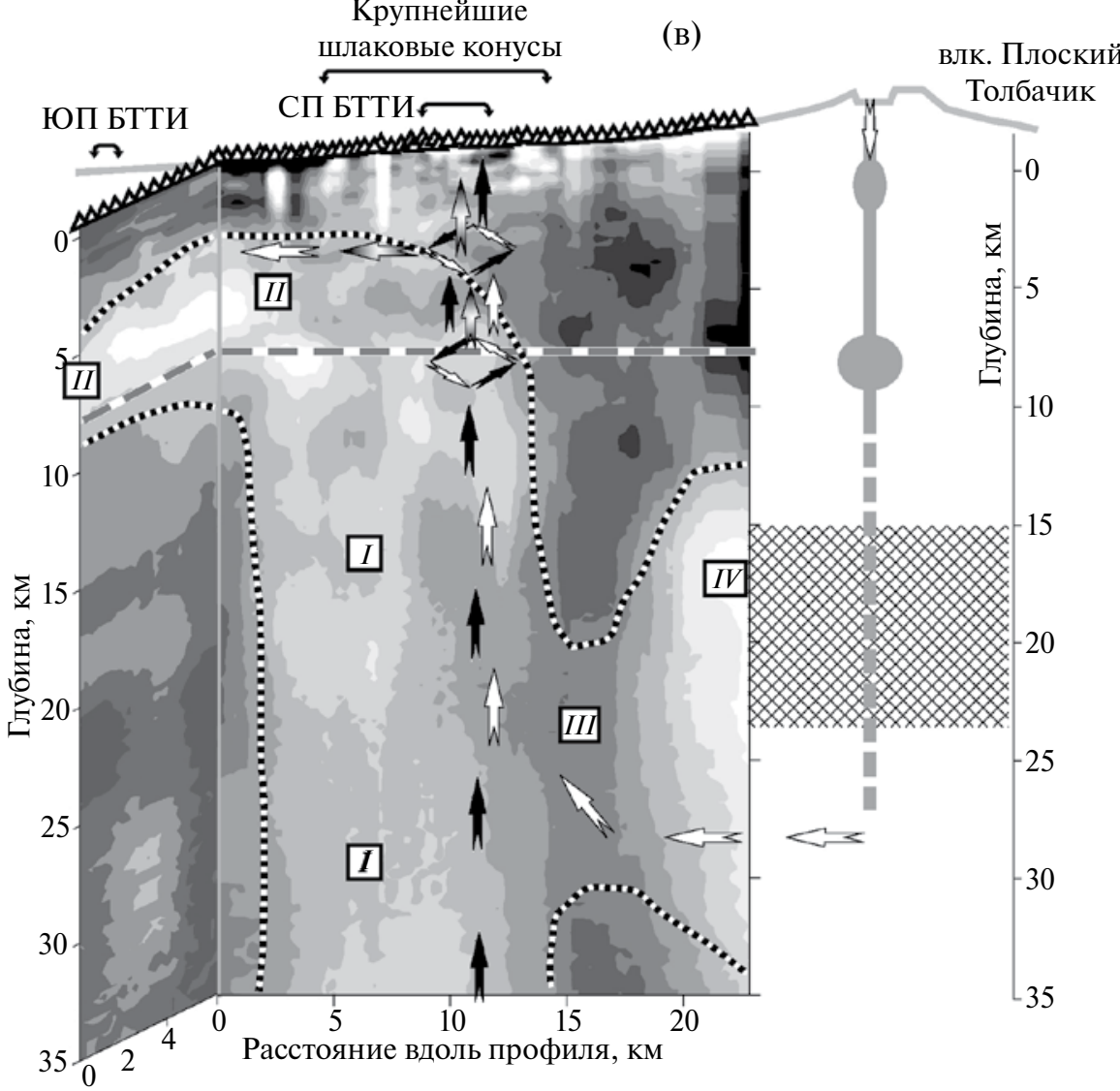

(B)

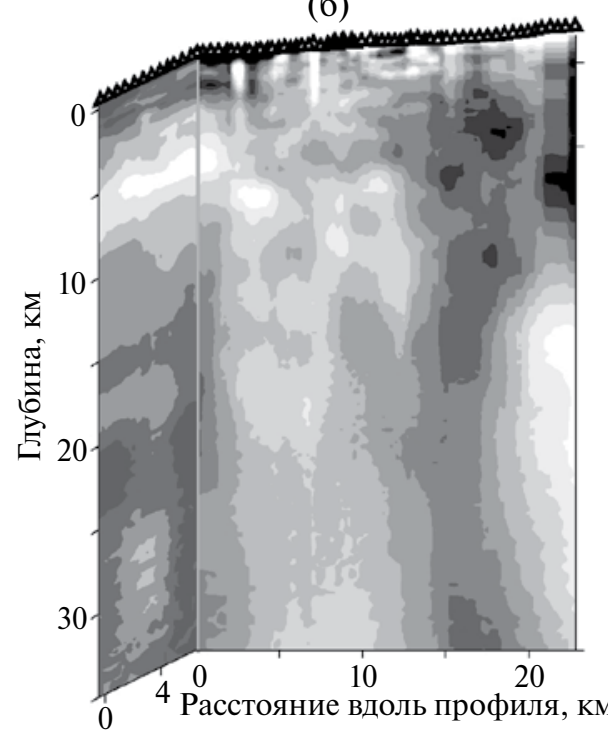

20

ЛЯ, КМ
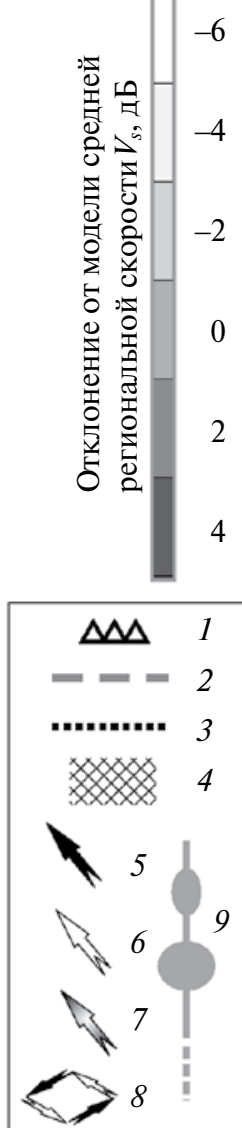

Рис. 2. Вертикальные разрезы, отражающие глубинное распределение относительных скоростей сейсмических волн, вдоль отмеченных на схеме полигона ММЗ-профилей до подножия вулкана Плоский Толбачик (квази-3D-представление): (а) - схема полигона; (б) - оригинальный разрез, (в) - разрез с элементами интерпретации: 1 - реперы микросейсмической съемки; 2 - граница кристаллического фундамента; 3 - границы выявленных низкоскоростных аномалий; 4 - слой нейтральной плавучести базальтов по [Федотов и др., 2010]; элементы магматического питания БТТИ по схеме, составленной Г.Б. Флеровым [Федотов и др., 1991]: 5 - высокомагнезиальные базальты; 6 - глиноземистые базальты; 7 - их промежуточные разности; 8 - зоны смешения базальтов в малоглубинных магматических камерах; 9 - канал и магматические очаги под вулканом Плоский Толбачик. На схеме полигона крестом отмечено положение древнего кратера вулкана Плоский Толбачик по [Флеров и др., 2015]. Низкоскоростные зоны $\boldsymbol{I}-\boldsymbol{I V}$ обсуждаются в тексте. Скобками выделены зоны Северного и Южного прорывов БТТИ 1975-1976 гг. и участок крупнейших шлаковых конусов в центральной части Толбачинского Дола. 

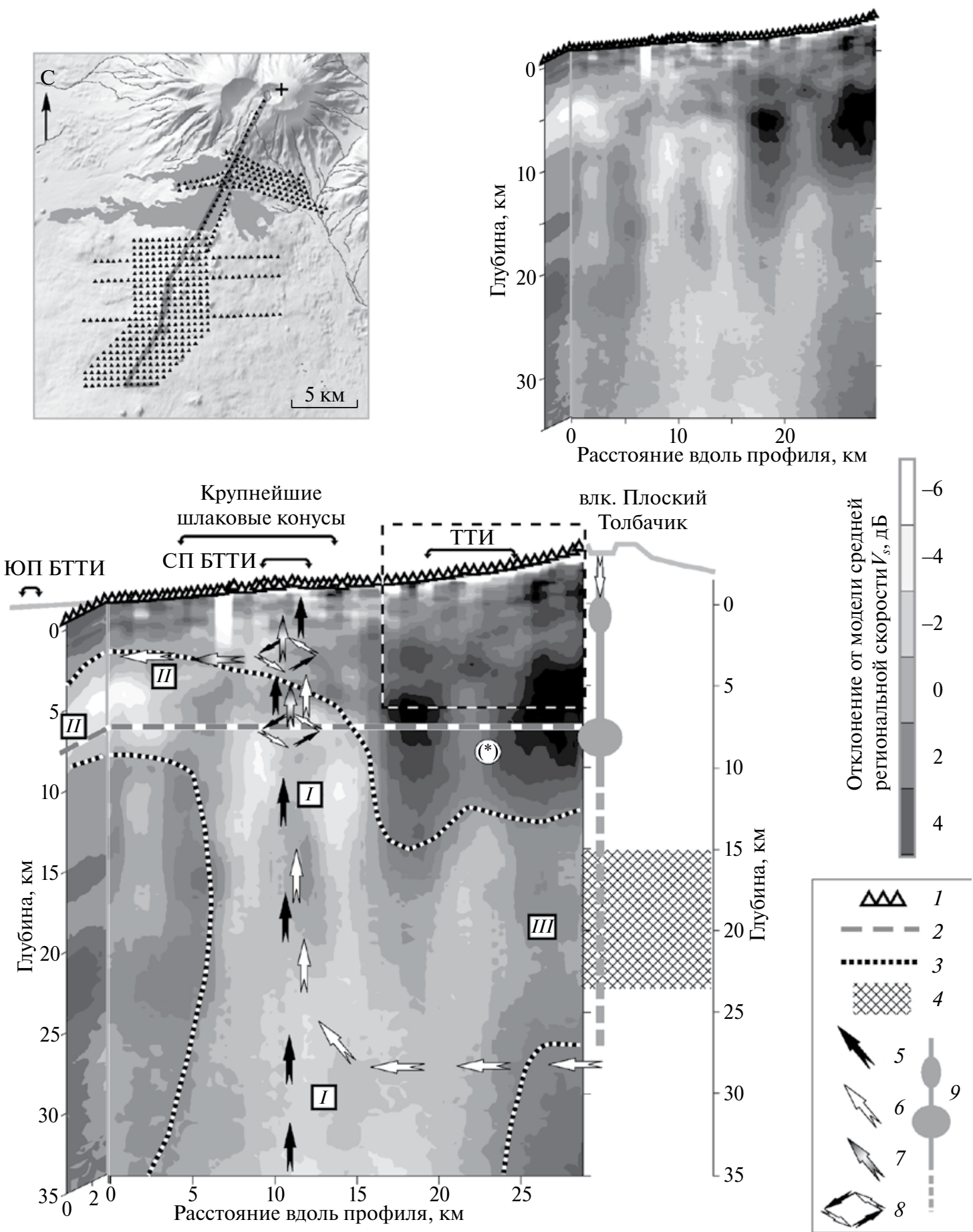

Рис. 3. Вертикальные разрезы, отражающие глубинное распределение относительных скоростей сейсмических волн, вдоль отмеченных на схеме полигона ММЗ-профилей до вершины вулкана Плоский Толбачик (квази-3D-представление). Структура рисунка и условные обозначения соответствуют рис. 2. Прямоугольником выделена зона ТТИ, которая более детально представлена на рис. 4.

достаточной контрастностью на фоне других аномалий на рис. 3. Поэтому он представлен отдельно на рис. 4а. На ММЗ-разрезе выделена низкоскоростная аномалия, которая начинается на глубине 1-4 км под вулканом Плоский Толбачик, а затем распространяется к югу и вверх, выходя к поверхности под протяженной зоной ТТИ.

\section{Профили, пересекающие трещину ТТИ}

На рис. 5 изображены три разреза вдоль профилей, пройденных в 2014 г., после ТТИ, в крест трещинной зоны в районе основного действовавшего эруптивного центра ТТИ. Два из этих разрезов соответствуют двум параллельным профилям, 
(a)
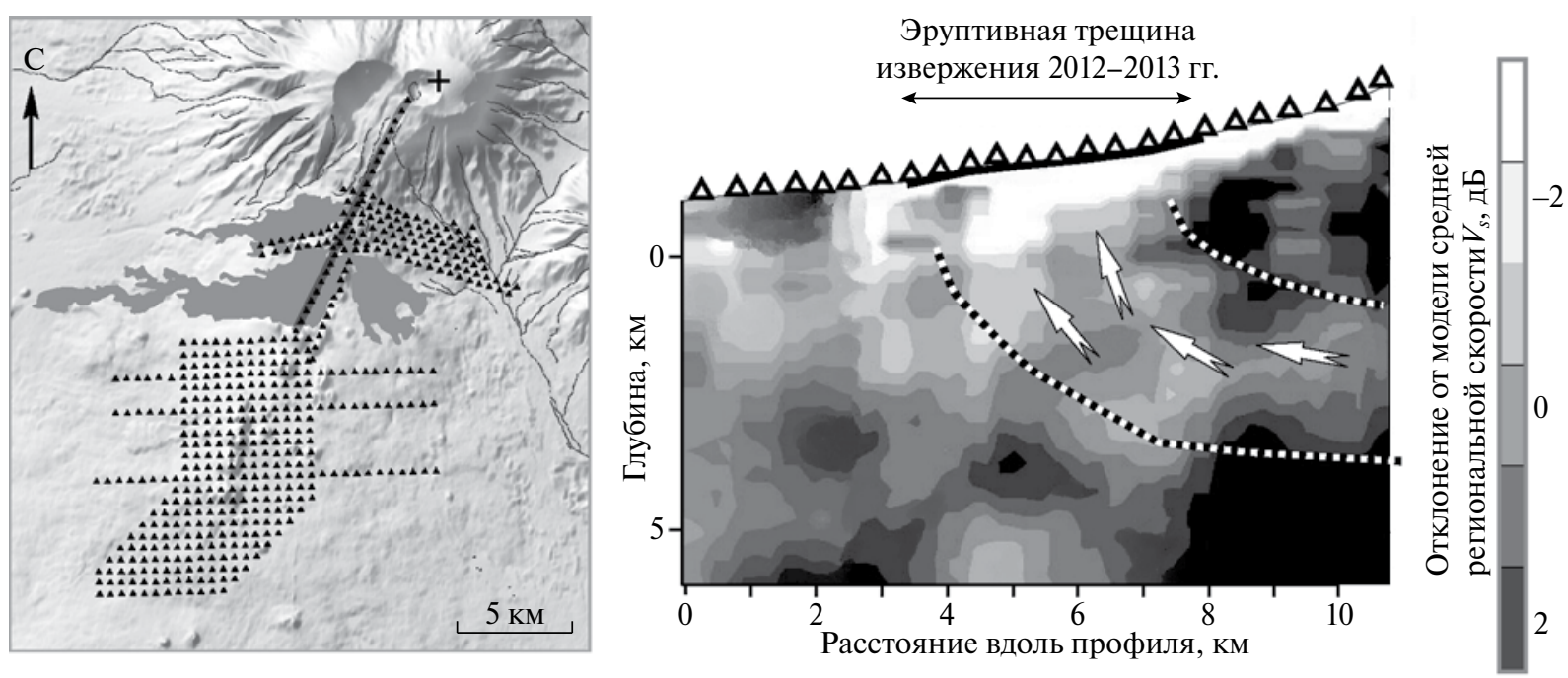

(б)
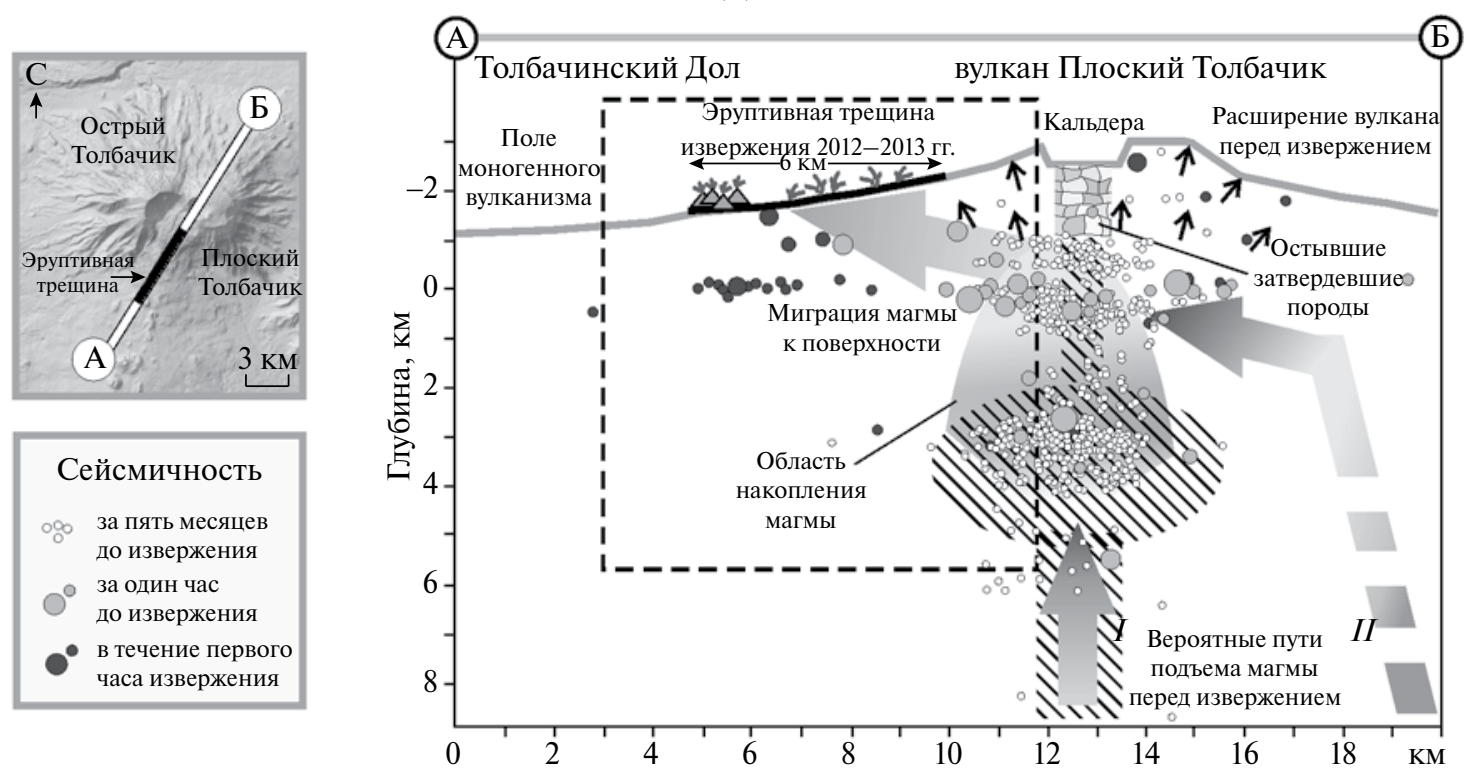

Рис. 4. Зона ТТИ 2012-2013 гг. (выделена прямоугольником на рис. 3 и рис. 4б):

(а) - вертикальные разрезы, отражающие глубинное распределение относительных скоростей сейсмических волн, по профилю вдоль эруптивной трещины извержения (по данным 2014 г.). Обсуждение в тексте. Обозначения соответствуют рис. 2; (б) - схематическое представление системы питания ТТИ в соответствии с работой [Ермаков и др., 2014; Федотов и др., 2014; Добрецов и др., 2016; Kugaenko et al., 2015; Lundgren et al., 2015]. Заштрихована магматическая камера по работе [Федотов и др., 2011]. Возможные пути подъем магмы ТТИ к поверхности: $I$ по работе [Kugaenko et al., 2015], II по работе [Caudron et al., 2015].

расстояние между которыми 350 м. При построении третьего разреза были использованы все данные, полученные на указанных профилях. Профили обозначены на сопутствующих схемах полигона. Все три разреза указывают на существование низкоскоростной аномалии в диапазоне глубин $\sim 10-25$ км. Изображения схожи. Можно говорить о том, что аномалия, полученная по независимым данным микросейсмической съемки, устойчива, что подтверждает ее достоверность. Аномалия не выходит на поверхность и соответствует глубинной магмосодержащей структуре, проявившейся на рис. 2 и рис. 3 (зона III) и отвечающей, по нашему мнению, за перемещения магмы вдоль рифта по работе [Федотов, 2010]. Выявленная аномалия пространственно не связана с поверхностным эруптивным центром, так как ТТИ питалось малоглубинной дайкой, уходящей наклонно под 

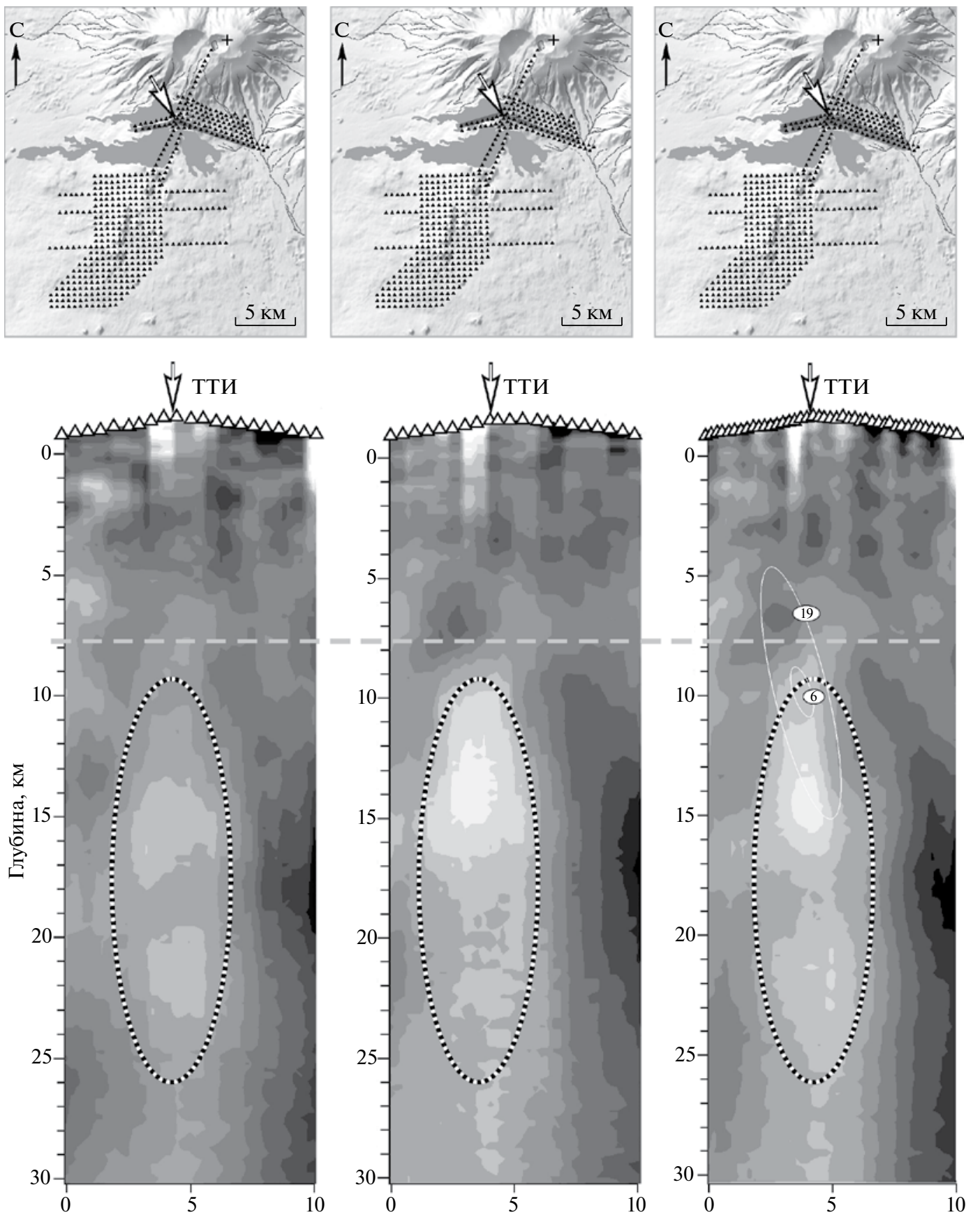

Расстояние вдоль профиля, км

Расстояние вдоль профиля, км
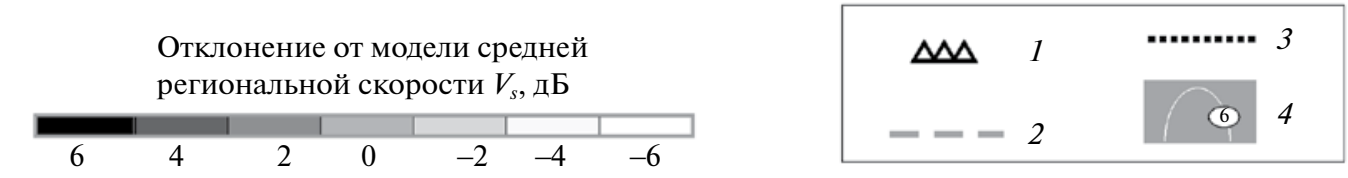

Рис. 5. Вертикальные разрезы, отражающие глубинное распределение относительных скоростей сейсмических волн, вдоль отмеченных на схемах полигона ММЗ-профилей вкрест эруптивной трещины ТТИ (по данным 2014-2015 гг.). 1-3 соответствуют рис. 2; 4- аномалия пониженного электросопротивления (в Омм), выделенная АМТЗ, по работе [Мороз, Логинов, 2016]. На схеме полигона стрелкой отмечено пересечение профилей с эруптивной трещиной ТТИ. 
вулкан Плоский Толбачик. На скомпилированный разрез (рис. 5, справа) наложены элементы геоэлектрического разреза по профилю $\mathrm{AMT}^{3}$ [Moроз, Логинов, 2016], пройденному одновременно с ММЗ-съемкой через прорыв ТТИ. Это узкая зона пониженного до 6 Ом·м удельного геоэлектрического сопротивления (диапазон глубин 5-15 км, ширина $\sim 700$ м), которая интерпретируется авторами как область, содержащая магматические расплавы. Геоэлектрическая неоднородность по AMT3 не противоречит выявленной нами низкоскоростной аномалии и ее интерпретации.

\section{Профили вкрест центрального участка Толбачинского Дола}

Рассмотрим разрезы в южной части полигона, представленные на рис. 6, проходящие через трешинные прорывы, возраст которых не превышает 2 тыс. лет. Отметим, что все три прорыва относятся к центральному участку Толбачинского Дола и пересекают низкоскоростную аномалию I (рис. 2, рис. 3).

Реконструкция истории вулканической активности Толбачинского Дола показывает сходство деятельности этих трех прорывов [Брайцева и др., 1984]. Для них характерна смена состава изверженных базальтов от $\mathrm{Mg}$-базальтов через промежуточные разности к Al-базальтам, завершающим извержение.

Первый профиль был заложен через шлаковый конус Алаид (возраст - 1-1,5 тыс. лет). Второй пересек основную эруптивную трещину и цепочку конусов Северного прорыва БТТИ. Третий профиль прошел еще на 3 км южнее, через область двух связанных одной трещиной и пространственно сближенных извержений, возраст которых оценивается в $\sim 1-\sim 2$ тыс. лет. Далее в тексте статьи этот комплекс шлаковых конусов будем называть прорывом 1004 (в соответствии с [Большое..., 1984]).

На разрезах выделяются относительно низкоскоростные аномалии, которые могут быть магмоводами или объемами среды, содержащими некоторое количество магмы. Сопоставление показывает, что разрезы аналогичны, на них выделяются схожие неоднородности. Отметим, что аномалии расположены несимметрично по отношению к положению прорывов на земной поверхности, на всех трех разрезах они сдвинуты в западном направлении и частично даже уходят за пределы полигона. Структуры, выделяющиеся под трещинными прорывами в южной части полигона (рис. 6), отличаются от аномалии под ТТИ (рис. 5) и имеют более сложное строение.

\footnotetext{
${ }^{3}$ АМТЗ - аудиомагнитотеллурическое зондирование
}

Разрез через зону Северный прорыв БТТИ может рассматриваться как базовый, что обусловлено изученностью этого извержения. Низкоскоростные неоднородности, выявленные под этим прорывом, более подробно разбираются в работе [Кугаенко и др., 2011; 2013a].

На рис. 6 на полученный нами разрез под $\mathrm{Ce}$ верным прорывом БТТИ наложены контуры неоднородностей (возможно, малоглубинных магматических очагов), обнаруженных при БТТИ на глубинах 2-3 км и 7-8 км по геофизическим данным и представленных в работах [Большое..., 1984; и др.]. Выявленные нами низкоскоростные неоднородности В2-2 и С2 хорошо согласуются с положением этих магматических камер.

Учитывая схожесть разрезов через трещинные прорывы на рис. 6, а также принимая во внимание результаты работ [Балеста, 1981; Большое..., 1984; Ермаков, Геншафт, 1980, Ермаков В.А., Ермаков А.В., 2006; Федотов 1991; 2011; и др.], выявленные под прорывами низкоскоростные области мы интерпретируем следующим образом:

A1-A3, глубина 15-20 км (переход от "базальтового” к “гранитному” слою, граница Конрада) - верхняя часть зоны генерации магмы под центральной частью Толбачинского Дола;

В1-В3, глубина 6-8 км (граница кристаллического фундамента) - области промежуточных магматических очагов;

C1-C3, глубина 2-3 км (осадочная толща) - области близповерхностных периферических магматических очагов.

Субвертикальные низкоскоростные структуры, соединяющие между собой эти объекты, рассматриваются нами как магмопроводящие зоны. В соответствии с этой интерпретацией на разрезах выделяются две системы таких магмоводов: непосредственно под линией шлаковых конусов (центральная) и смещенная к западу. Полученная конфигурация магматической системы позволяет предположить, что базальты разного состава могли подниматься к зонам извержений разными путями, а выделенные нами области, ассоциирующиеся с магматическими камерами, могут выступать в роли областей смешения расплавов. Возможные пути распространения базальтов мы условно проиллюстрировали стрелками на рис. 6. На разрезах пути продвижения магмы к поверхности в кристаллическом фундаменте (на глубинах больше 7-8 км) имеют субвертикальный характер, а в вулканогенно-осадочной оболочке форма магмоводов меняется: мы видим наклонные и силлоподобные структуры без ярко выраженных вертикальных каналов.

Как видим, на всех трех разрезах на рис. 6 восточный край основной аномалии (магмовода), не- 


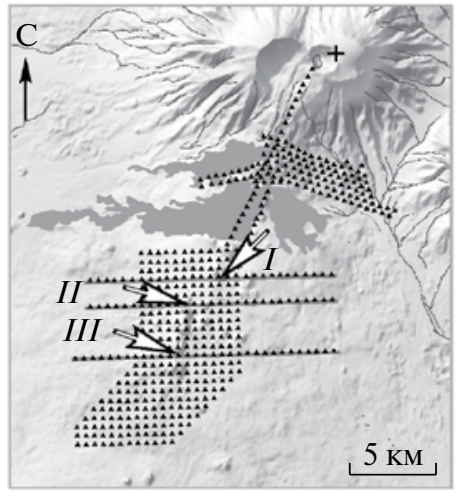

Трещинные прорывы:

I Прорыв Алаид II Северный прорыв БТТИ III Прорыв 1004
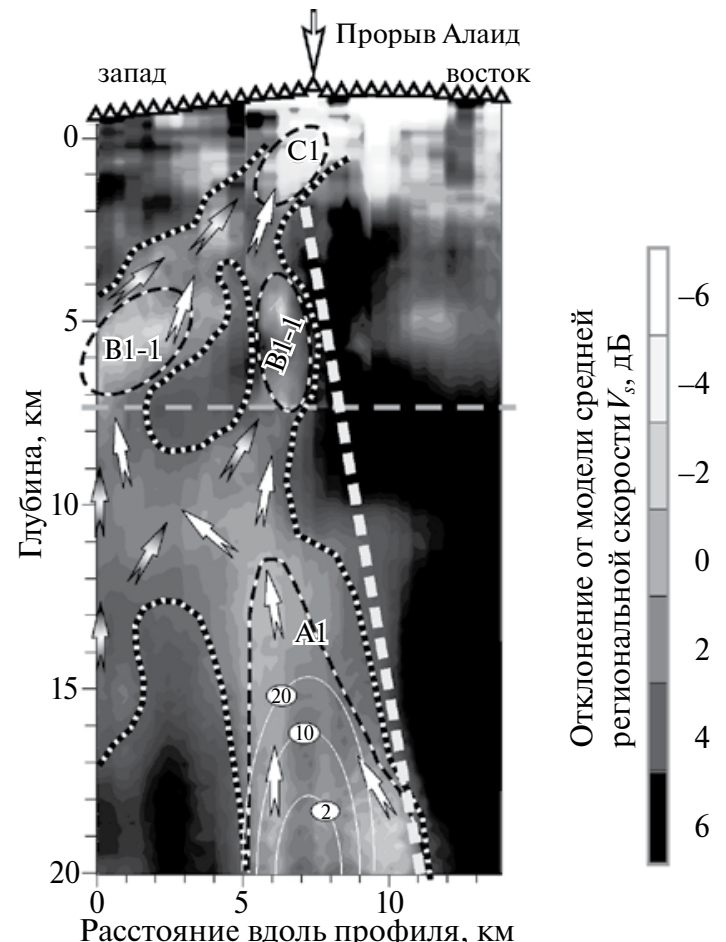

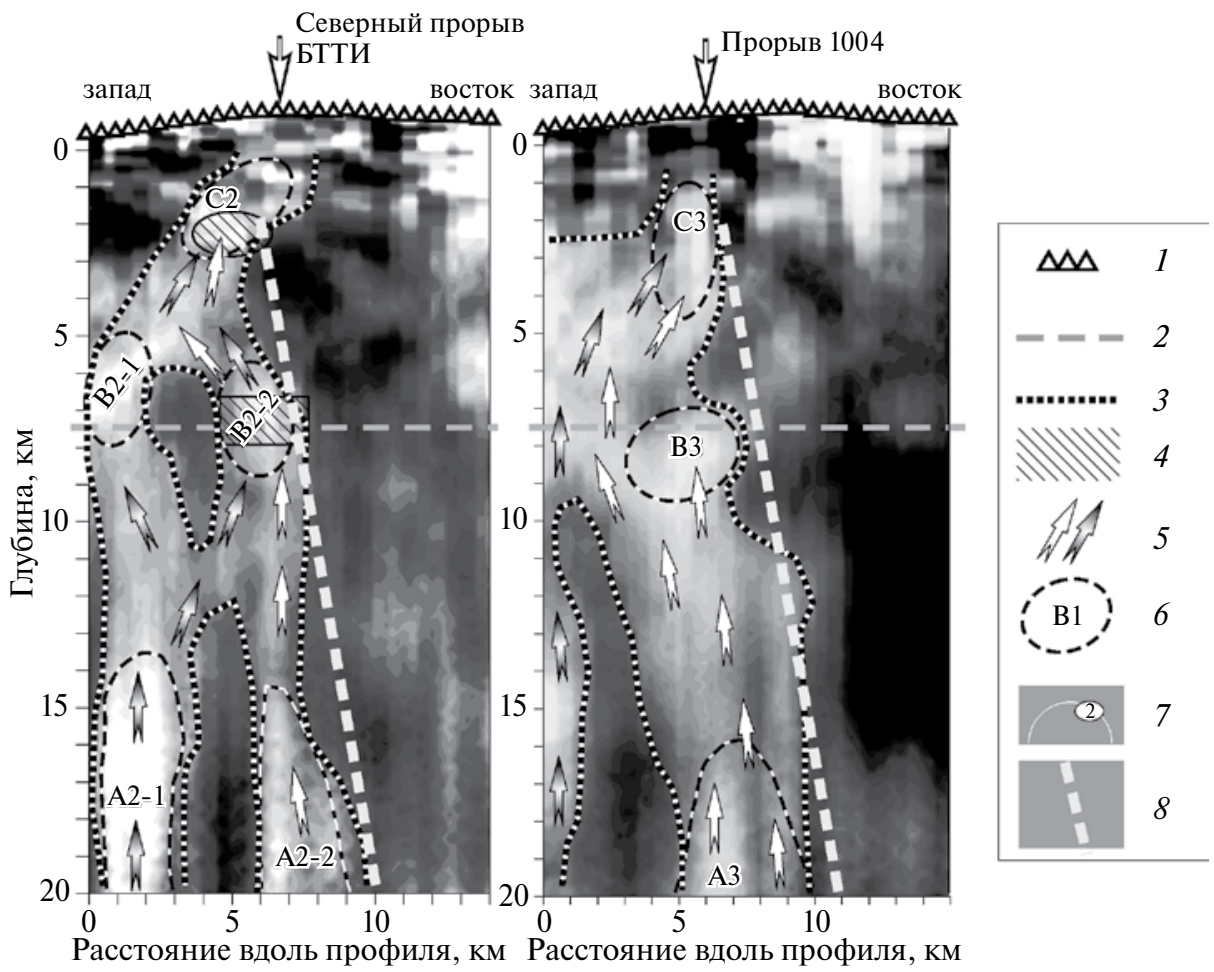

Рис. 6. Вертикальные разрезы, отражающие глубинное распределение относительных скоростей сейсмических волн вдоль трех отмеченных на схеме полигона ММ3-профилей вкрест магмопроводящего разлома: 1-3 соответствуют рис. 2; 4 - аномалии, выявленные под СП БТТИ на глубине 2-3 км и на границе кристаллического фундамента, на глубине 7-8 км, по работе [Большое ..., 1984], проинтерпретированные как возможные магматические очаги; 5 - возможные пути продвижения базальтов разного состава (раскраска условная); 6 - границы выделенных наиболее низкоскоростных областей; 7 - аномалия пониженного электросопротивления (в Ом·м), выделенная МТЗ в районе прорыва Алаид, по работе [Мороз, Логинов, 2016]; 8 - предположительно восточный борт плоскости глубинного магмоподводящего разлома. 
смотря на неровности, имеет наклон под углом $\sim 80^{\circ}$. Возможно, так при применении ММЗ проявляет себя глубинный разлом. Отметим, что на этой его особенности неоднократно заострял внимание В.А. Ермаков: по его мнению, широкая, насыщенная магмой плоскость глубинного разлома круто падает на юго-восток под углом 75-85 $[\mathrm{Ep}$ маков В.А., Ермаков А.В., 2006; Ермаков и др., 2014; и др.].

Обращают на себя внимание низкоскоростные аномалии, расположенные выше границы кристаллического фундамента в восточной части всех трех разрезов. Мы связываем их с областью современных сейсмических проявлений и выделенной в ходе БТТИ Толудской эпицентральной зоной, которая проявляла повышенную сейсмическую активность как в ходе БТТИ, так и в начале ТТИ [Большое..., 1984; Кугаенко и др., 2015а]. В ряде работ [Ермаков и др., 2014; Belousov et al., 2015; Koulakov et al., 2017; и др.] предполагается связь зоны Толудских землетрясений с магматической питающей системой Ключевской группы вулканов. Наши микросейсмические профили достигли лишь западного края эпицентральной зоны, поэтому мы пока не можем участвовать в обсуждении этих гипотез. Этот сектор Ключевской группы вулканов требует дополнительных комплексных исследований.

\section{ОБСУЖДЕНИЕ РЕЗУЛЬТАТОВ}

\section{О привлечении дополнительной геолого- геофизической информации}

Полученные с помощью ММЗ результаты мы сопоставляли с разнообразными моделями и данными других методов, применявшихся для исследования Толбачинского Дола, вулкана Плоский Толбачик и последних наблюдавшихся здесь трещинных извержений.

Это геологические представления об истории формирования Толбачинского регионального поля ареального вулканизма. Так в работах [Ермаков, Важеевская, 1973; Ермаков и др., 2014; Брайцева и др., 1984; Флеров и др., 2015; Churikova et al., 2015a] предполагается, что к началу голоцена, когда начала формироваться ареальная зона, вулкан Плоский Толбачик уже потерял самостоятельную активность и теперь является лишь одним из эруптивных центров поля ареального вулканизма. Такой подход предполагает возможность деградации его собственной, свойственной стратовулкану, магматической системы, на смену которой сформировались новые питающие каналы, характерные для зон трещинных извержений.
Это петрологическая модель смешения магматических расплавов, объясняющая разнообразие состава продуктов извержений в последние 2 тыс. лет [Волынец и др., 1978; Федотов и др., 1991; Флеров и др., 1984] и некоторые альтернативные ей представления.

Особенности глубинного строения, положение границ, глубины предполагаемых зон магматического питания и магматических камер были определены для исследуемого района по результатам геофизических изысканий, в основном, на стадии всестороннего изучения БТТИ в 70-х годах XX века [Аносов и др., 1978; Балеста, 1977; 1981; Балеста и др., 1991; Зубин, 1976; Смирнов, 1979; Федорченко, 1980; Большое..., 1984; и др.]. В ходе исследований ТТИ сейсмологические, GPS- и InSar- данные позволили создать представление о возможном положении магматической камеры на стадии подготовки извержения [Ермаков, 2014; Федотов, 2014; Кугаенко, 2015; Belousov, 2015; Kugaenko, 2015; Lundgren, 2015]. Геофизические исследования ТТИ ограничиваются, помимо ММЗ, двумя магнитотеллурическими профилями [Мороз, 2016]. Новые данные об условиях кристаллизации расплавов в магматических камерах (температура, давление, глубина) для Толбачинской зоны приведены в работе [Добрецов, 2016].

Еще один источник независимых данных - это результаты сейсмической томографии, широко использующейся в настоящее время для исследований внутреннего строения среды. Однако в первых опубликованных работах по томографии Ключевской группы вулканов [Гонтовая, 2004; 2008; Ермаков, 2014; Koulakov, 2011; 2013; Lees, 2007] район Толбачинского Дола оказывался на периферии или даже вне зоны надежных построений из-за относительно слабой локальной сейсмичности и удаленности от основной группы сейсмических станций. Построить сейсмотомографическую модель южной части Ключевской группы вулканов, включая Толбачинский Дол, удалось лишь по результатам специального сейсмотомографического эксперимента 2014-2015 гг. [Koulakov, 2017]. Для сопоставления результатов ММЗ с этой моделью важно следующее: согласно сейсмотомографической модели [Koulakov, 2017] для Толбачинского поля трещинных извержений предлагается три возможных зоны (колонны) питания (K1-K3 на рис. 7). Одна их них (K1) предположительно локализована под Толудской эпицентральной 3оной, вторая (K2) - под центральной частью Толбачинского Дола, захватывая Северный прорыв ТТИ, третья (К3) на глубине 10-15 км подходит с северо-востока под вулкан Плоский Толбачик, но она не является доминирующей. Отметим, что в явном виде ни малоглубинная магматическая камера, ни питающий канал непосредственно 


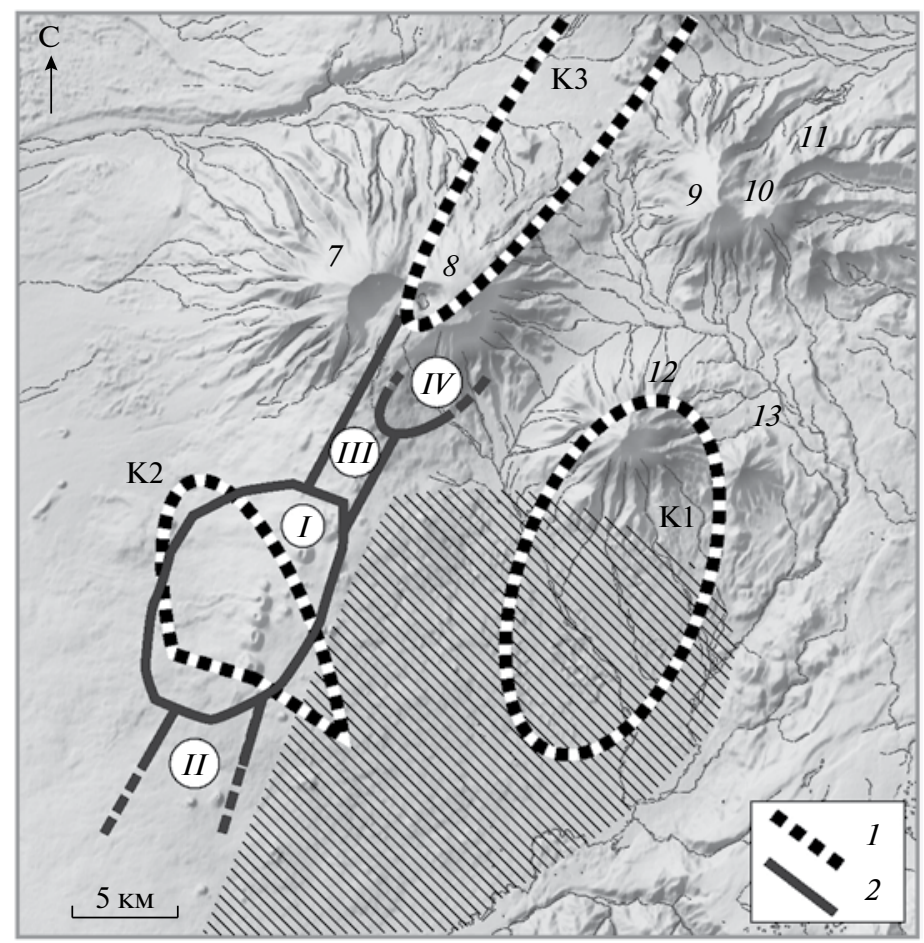

Рис. 7. Сопоставление результатов ММЗ с моделью, построенной по результатам сейсмической томографии в работе [Koulakov et al., 2017]. Контуры аномалий, интерпретируемых как элементы магматической питающей системы Толбачинской вулканической зоны: 1 - возможные каналы питания K1, K2, K3 по paбoтe [Koulakov et al., 2017], 2 - элементы магматической питающей системы $\boldsymbol{I}-\boldsymbol{I} \boldsymbol{V}$ по результатам ММЗ, обсуждающиеся в тексте данной статьи (пунктиром отмечено предполагаемое продолжение структур за границы полигона микросейсмической съемки). Номера вулканов соответствуют рис. 1. Штриховкой выделена Толудская эпицентральная зона.

под стратовулканом (как они описываются в работе [Федотов и др., 2011; Ермаков и др., 2014; Belousov et al., 2014]) по данным сейсмотомографии [Koulakov, 2017] не выделяются.

\section{Основные особенности внутреннего строения магматической питающей системы, выявленные с применением ММЗ}

Проведенные с помощью ММЗ исследования позволили впервые по инструментальным данным выделить и визуально представить основные элементы магматической питающей системы Толбачинского Дола, предполагавшиеся по результатам проводившихся ранее геолого-геофизических работ. Если обобщить представленные выше результаты наших исследований, то можно выделить основные особенности обнаруженных структурных аномалий. Обобщения носят гипотетический характер.

Распределение низкоскоростных включений, имеющих разную контрастность, в исследуемом объеме среды неоднородно. Наблюдаются различия в строении земной коры вдоль основного магмопроводящего разлома (рифта). На этом направлении доминирует крупная воздымающаяся аномалия под центральной частью Толбачинского Дола, которая пространственно соответствует поступлению на поверхность глубинных Mg-базальтов (зона $\boldsymbol{I}$ на рис. 2, рис. 3). Профили, пройденные через эту структуру, позволяют оценить ее размеры: 15-20 км вдоль разломной зоны (рис. 2, рис. 3) и 9-10 км в поперечном направлении (рис. 6). На всех разрезах магмоподводящая зона имеет четкие границы. Она расположена несимметрично относительно осевой линии разлома и сдвинута к западу. На поперечных разрезах этой зоны (рис. 6) выделяются субвертикальные структуры, которые можно проинтерпретировать как питающие каналы извержений, сконцентрированных вдоль цепочки шлаковых конусов. Важно, что конфигурация питающей системы допускает поступление базальтов к поверхности разными путями, то есть в пределах одного центра активности (трещинного прорыва) по близкорасположенным каналам могут распространяться, в частности, магмы разного состава. Питающие каналы имеют сложную форму, их особенностью является дифференцированный характер - чередование участков канала и ограниченных низкоскоростных областей, которые могли сформироваться в местах скопления или повышенного содержания магмы и могут интерпретироваться как магматические камеры. Каналы близки к вертикальным формам в кристаллическом фундаменте, испытывают 
некоторый излом на его границе и становятся наклонными на менее глубоких горизонтах.

Трещинные прорывы, через которые прошли представленные на рис. 6 разрезы, являются разнесенными во времени эпизодами, но пространственно близкими событиями эруптивной активности Толбачинского Дола. Очевидно, что схожесть этих вулканических построек, периодичность их расположения вдоль глубинного разлома [Викулин, 1984], общий характер эруптивной деятельности, а также обнаруженное нами подобие глубинных скоростных разрезов не случайны. Нами обнаружена и продемонстрирована закономерность в конфигурации питающих систем извержений средней части Толбачинской региональной зоны ареального вулканизма:

- на глубинах 15-20 км располагается верхняя часть зоны магматического питания трещинных прорывов, которая может быть единой для всей цепочки эруптивных центров в осевой части Толбачинского Дола;

- магмоподводящая колонна в диапазоне глубин до $\sim 20$ км представляет собой многоканальную систему, осложненную магматическими камерами;

- промежуточные магматические очаги формируются близ границы кристаллического фундамента в диапазоне глубин 6-9 км;

- верхние малоглубинные очаги располагаются непосредственно под зоной прорыва в диапазоне глубин 1.5-4 км;

- магматические камеры и питающие каналы в этой части Ключевской группы вулканов являются долгоживущими структурами и продолжают существовать в качестве аномальных низкоскоростных включений даже при длительном отсутствии извержений.

В целом зону $\boldsymbol{I}$ можно рассматривать как самостоятельную, локальную, пространственно обособленную транскоровую зону флюидо- и магмопроводимости в южной части Ключевской группы вулканов. Ее существование подтверждается результатами специально организованных в 20142015 гг. сейсмотомографических исследований [Koulakov et al., 2017]: в этой публикации показано, что одна из возможных колонн магматического питания Толбачинского Дола расположена под его центральной частью, в районе Северного прорыва БТТИ (К2 на рис. 7).

Область, тяготеющая к южной границе полигона, отличается отсутствием субвертикальных форм, но здесь на глубине 4-8 км выделяется субгоризонтальная низкоскоростная аномалия (зона II на рис. 2, рис. 3), смыкающаяся в своей северной части с зоной I. Разрез вдоль крайней южной линии реперов показывает сечение этой структуры, уходящей на юг за пределы полигона (рис. 2). Выделенная аномалия увязывается с гипотезой о существовании сублатерального малоглубинного магмовода, по которому базальты перемещаются в южную часть Толбачинского Дола, как это происходило в ходе БТТИ [Большое ..., 1984; Магуськин, и др., 2003; и др.]. Этот процесс проиллюстрирован на рис. 2 , рис. 3 стрелками (в соответствии с моделью смешения магм и схемой магматического питания БТТИ по рис. 180 из работы [Федотов, 2011]).

Под северным участком Толбачинского Дола, переходящим в постройку вулкана Плоский Толбачик, структура среды отличается от двух обсуждавшихся выше сегментов. Основная особенность этого участка - низкоскоростная сублатеральная аномалия, продолжающаяся под вулкан Плоский Толбачик (зоны $\boldsymbol{I I I , ~} \boldsymbol{I V}$ на рис. 2, рис. 3). Ее поперечное сечение можно видеть на рис. 5. Вытянутая по высоте неоднородность лежит в диапазоне глубин $\sim 10-25$ км, линейный размер ее наиболее контрастной части по горизонтали $\sim 5$ км. По профилю, представленному на рис. 3 , аномалия имеет тенденцию к заглублению под стратовулкан, где становится более контрастной. Эту низкоскоростную структуру можно интерпретировать как сублатеральный магмовод, по которому расплавы могут мигрировать вдоль разломной зоны [Федотов, 2010]. Существование такого сублатерального магмовода обсуждалось в работе [Большое..., 1984], но в то время не удавалось определиться с глубиной его залегания (сейсмологические данные свидетельствовали в пользу малоглубинной миграции магмы). Тем не менее в модели смешения магматических расплавов БТТИ [Федотов и др., 2011], которую мы для сравнения приводим на рис. 2, рис. 3, предполагаемая глубина миграции Al-базальтов из-под вулкана Плоский Толбачик близка к глубине выделенной по ММЗ аномалии. Таким образом, наши результаты являются дополнительным аргументом в пользу существования сублатеральной зоны магмопроводимости, выходящей из-под вулкана Плоский Толбачик именно в диапазоне глубин $\sim 15-25$ км. По этому слою возможно проникновение расплавов из северной части Ключевской группы вулканов в южную (под вулкан Плоский Толбачик и Толбачинский Дол).

\section{Вулкан Плоский Толбачик и ТТИ}

На ММ3-разрезе (рис. 4а) на глубине 1-4 км под вулканом Плоский Толбачик обнаружена низкоскоростная аномалия, которая достигает поверхности под зоной ТТИ. Для сопоставления с результатами ММЗ обобщим сформировавшиеся ранее представления о магматической камере ТТИ. 
По мнению С.А. Федотова [Федотов и др., 2011], под Плоским Толбачиком существует обширный магматческий очаг, который занимает диапазон глубин 2-6 км и имеет диаметр 5-6 км. Ряд исследований начальной фазы ТТИ свидетельствуют о том, что магма поступила к поверхности изпод постройки вулкана Плоский Толбачик с глубины 0-5 км, где в течение нескольких месяцев до извержения фиксировалась повышенная сейсмическая активность, а ТТИ происходило по типу бокового прорыва, как это схематично представлено на рис. 4б [Ермаков и др., 2014; Кугаенко и др., 2015в; Федотов и др., 2014, Kugaenko et al., 2015]. Аналогичная оценка глубины магматической камеры ( 2-3 км) приведена в работе [Добрецов и др., 2016], она получена при расчете физико-химических параметров образования кристаллов-лапиллей плагиоклаза в ходе ТТИ. Кроме того, по данным спутниковой интерферометрии, питающая система ТТИ соответствует внедрению радиальной наклонной дайки с глубины $\sim 2$ км [Lundgren et al., 2015]. Таким образом, оценки глубины магматической камеры под Плоским Толбачиком по данным разных авторов достаточно близки.

Резюмируя эти данные, можно предполагать, что низкоскоростная ММ3-аномалия на рис. 4а соответствует области накопления магмы и развития питающих даек извержения, которые частично наследовали пути более ранних трещинных прорывов на южном склоне и у подножия стратовулкана. В целом выделенная по ММЗ структура хорошо согласуется с приведенными представлениями о ТТИ как внедрении радиальной дайки на склоне вулкана Плоский Толбачик, однако ожидаемая малоглубинная магматическая камера не выявляется на ММЗ-разрезе в качестве самостоятельного элемента. Для осмысления этого факта может быть привлечена гипотеза о том, что среда под вулканами в ряде случаев быстро меняет физические свойства между периодами активизации и покоя [Добрецов и др., 2012; 2015; Koulakov et al., 2013; Kasatkina et al., 2014]: предполагается, что малоглубинные очаги могут появляться на стадии подготовки извержения, а затем деградировать или исчезать в течение даже нескольких месяцев. Поэтому полученный ММ3-разрез (рис. 4а) может содержать информацию лишь об остаточной части уже трансформировавшейся (деградировавшей в течение одного года после ТТИ) малоглубинной магматической камере, частично уходящей за пределы ММЗ-профиля.

Отметим, что на рис. 3 и рис. 4 не проявляется питающий канал вулкана Плоский Толбачик. Возможно, разрезы не захватили “корня” вулкана, так как последний репер ММЗ-профиля расположен лишь на краю вершинной кальдеры. Но с другой стороны, малоглубинные магматические очаги этого вулкана не выделялись и по результатам томографических исследований [Koulakov et al., 2017]. Так в этой работе показано, что структура, трактуемая как возможный питающий канал Плоского Толбачика (К3 на рис. 7), уверенно выявляется на глубинах больше 10 км, уходя на северо-восток, заглубляясь и соединяясь с обширной зоной магматического питания вулканов Безымянный и Ключеской [Ivanov et al., 2016]. А на глубинах до 10 км канал маркируется, в основном, лишь локальной сейсмичностью. Это может свидетельствовать в пользу предположения, что магматический канал и очаг Плоского Толбачика, питавшие вулкан в эпоху его самостоятельной активности, сильно разрушились и видоизменились под воздействием эруптивной деятельности наложенной зоны ареального вулканизма. В результате в настоящее время структура канала Плоского Толбачика такова, что он не является доминирующей неоднородностью, влияющей на спектр поля микросейсм, а его конфигурация остается неизвестной и может отличаться от традиционной субвертикальной магмопроводящей “трубы”.

\section{ЗАКЛЮЧЕНИЕ}

Глубинное строение магматической системы и питающих каналов Толбачинского Дола исследуется с использованием технологии пассивной сейсморазведки - метода низкочастотного микросейсмического зондирования. В 2010-2015 гг. проведены специально спланированные полевые работы на детально размеченном полигоне, где была проведена регистрация фонового микросейсмического излучения. Полигон включает несколько линейных профилей и область эквидистантной площадной съемки. Съемкой охвачен участок эруптивной активности последних $\sim 2$ тыс. лет, включая зоны исторических Толбачинских извержений 1975-1976 гг. и 2012-2013 гг., а также частично постройку вулкана Плоский Толбачик.

По данным микросейсмической съемки построены глубинные разрезы, отражающие распределения относительных скоростей поперечных сейсмических волн.

Для повышения достоверности интерпретации выявленных глубинных неоднородностей проанализирован и привлечен обширный материал независимых геолого-геофизических исследований, проводившихся в разное время в исследуемом районе, в том числе результаты сейсмотомографического эксперимента 2014-2015 гг. В результате комплексирования результатов ММЗ с этими данными можно описать основные выделенные элементы сложной магматической питающей системы Толбачинского Дола: 
- сублатеральная структура на глубинах 1525 км под вулканом Плоский Толбачик - возможный путь миграции расплавов (глиноземистых базальтов) из северной части Ключевской группы вулканов;

- долгоживущая транскоровая область магмопроводимости под центральной частью Толбачинского Дола, обеспечивающая поступление на поверхность преимущественно более глубинной магнезиальной магмы из горизонтов 35-60 км;

- малоглубинный сублатеральный магмовод на глубине 4-8 км, уходящий вдоль рифта от центральной в южную часть Толбачинского Дола, по которому перемещаются преимущественно магмы промежуточного состава после смешения.

Под тремя разновозрастными трещинными прорывами в центральной части Толбачинского Дола, включая Северный прорыв Большого трещинного Толбачинского извержения 1975-1976 гг., впервые показаны упорядоченные элементы магматической системы, которые представляют собой близкорасположенные субвертикальные магмоводы с магматическими камерами на глубинах 6-9 км и 1.5-4 км. Взаиморасположение "корней" этих трещинных прорывов предполагает возможность подъема базальтов к поверхности разными путями, что может объяснять, в частности, одновременное поступление на поверхность магм контрастного состава в ходе единого извержения. Показано, что элементы магматической питающей системы под тремя изученными трещинными прорывами схожи между собой. Повторяемость результатов вдоль трех профилей свидетельствует в пользу того, что выявленные глубинные структуры действительно существуют. Следовательно, можно выдвинуть предположение, что обнаружена закономерность в конфигурации питающих систем извержений средней части Толбачинской региональной зоны ареального вулканизма.

Исследование района Трещинного Толбачинского извержения 2012-2013 гг. показало, что его наклонный питающий канал выходит из-под вулкана Плоский Толбачик с глубины 1-4 км, что соответствует внедрению радиальной дайки. Область магматической камеры, питавшей это извержение, слабо проявляется на разрезах ММЗ, что предположительно может свидетельствовать о ее деградации после завершения эруптивного процесса.

В отличие от зоны питания ТТИ, магматические камеры и питающие каналы под центральной частью Толбачинского Дола ярко проявляются на MМ3-разрезах. Это говорит о том, что в этой части Ключевской группы вулканов в земной коре существует сквозькоровая колонна, в которой магматический расплав может присутствовать даже при длительном отсутствии извержений.
Таким образом, в представленном исследовании показано, что элементы системы магматического питания для разных сегментов Толбачинского Дола различны. Выявлена сложная глубинная структура, объединяющая субвертикальные и латеральные участки, включающая магматические камеры и подводящие каналы. Наши результаты расширяют представления о возможной конфигурации областей питания крупных полей ареального вулканизма, которые рассматривались ранее как совокупность преимущественно примитивных субвертикальных временных магмоводов. Новые данные могут быть полезны при исследовании аналогичных вулканических объектов не только на Камчатке, но и в других районах мира.

Авторы благодарят всех своих коллег, принимавших участие в проведении микросейсмической съемки. Без их поддержки представленное исследование не могло бы состояться. Это сотрудники Камчатского филиала ФИЦ ЕГС РАН П.В. Воропаев, И.Ф. Абкадыров, И.Н. Нуждина, Н.М. Кравченко, А.А. Коновалова, Е.О. Макаров, Е.Р. Махмудов. При полевых работах неоценимое содействие оказали водители автомобилей повышенной проходимости С.И. Богатов, А.А. Щегольков, С.И. Пикун, А.В. Клепиков.

Значительный вклад в повышение качества статьи внесли рецензенты, внимательно изучившие рукопись и сформулировавшие ряд важных полезных замечаний. Мы сердечно их благодарим.

Исследования выполнены при поддержке научных проектов РФФИ (гранты на инициативные проекты № 10-05-00139 и № 13-05-00117; гранты на проведение научных экспедиций № 10-0510059, 11-05-10059, 12-05-10038, 13-05-10033, 1405-10053).

\section{СПИСОК ЛИТЕРАТУРЫ}

Абкадыров И.Ф., Букатов Ю.Ю., Геранин К.О. Результаты микросейсмического зондирования в районе Авачинского вулкана. Материалы XIII Региональной молодежной научной конференции "Природная среда Камчатки”. Петропавловск-Камчатский: ИВиС ДВО РАН. 2014. C. $103-114$.

Абрамов А.А., Гиличинский Д.А. Геокриологические условия района Ключевской группы вулканов (Камчатка) // Криосфера Земли. 2008. Т. 12. № 1. С. 29-40.

Андреев В. И., Андреев А.В., Самкова Т.Ю., Соболевская $O . B$. Влияние Большого трещинного Толбачинского извержения (БТТИ) 1975-76 гг. на некоторые параметры окружающей среды в течение 30 лет // Вестник КРАУНЦ. Науки о Земле. 2006. Вып. 8. № 2. С. 163-176. Аносов Г.И., Биккенина С.Л., Попов А.А., Сергеев К.Ф., Федорченко В.И., Утнасин В.К. Глубинное сейсмическое зондирование Камчатки. М.: Наука. 1978. 130 с. 
Балеста С.T. Земная кора и магматические очаги областей современного вулканизма. М.: Наука. 1981. 133 с.

Балеста С.Т., Гонтовая Л.И., Каргапольцев А.А., Пак Г., Пушкарев В.Г., Сенюков С.Л. Результаты сейсмических исследований земной коры в районе Ключевского вулкана // Вулканология и сейсмология. 1991. № 3. С. 3-18. Балеста С.T., Каргопольцев А.А., Григорян Г.Б. Сейсмическое просвечивание Новых Толбачинских вулканов на Камчатке // Докл. АН СССР. 1977. Т. 237. № 2. С. 412415.

Большое трещинное Толбачинское извержение (Камчатка, 1975-1976) / Отв. ред. С.А. Федотов. М.: Наука. $1984.683 \mathrm{c}$.

Брайцева О.А., Мелекесиев И.В., Флеров Г.Б., Пономарева В.В., Сулержицкий Л.Д., Литасова С.Н. Голоценовый вулканизм Толбачинской региональной зоны шлаковых конусов. Большое трещинное Толбачинское извержение / Отв. ред. С.А. Федотов. М.: Наука. 1984. Гл. V. C. $177-222$.

Викулин A.B. О длине приповерхностной трещины, через которую осуществляется питание конусов Северного прорыва Толбачинского извержения 1975 г. // Вулканология и сейсмология. 1984. № 3. С. 82-87.

Волынеи, О.Н., Флеров Г.Б., Андреев В.Н., Пополитов Э.И., Абрамов В.А., Петров Л.Л., Щека С.А., Селиванова Г.И. Петро-геохимические особенности пород Большого трещинного Толбачинского извержения в связи с вопросами их генезиса. Геологические и геофизические данные о Большом Толбачинском извержении 1975-1976 гг. / Отв. ред. Федотов С.А., Мархинин Е.К. М.: Наука. 1978. С. 86-105.

Геологические и геофизические данные о Большом Толбачинском извержении 1975-1976 гг. / Отв. ред. Федотов С.А., Мархинин Е.К. М.: Наука. 1978. 256 с.

Гонтовая Л.И., Ермаков В.А., Сенюков С.Л., Назарова 3. $A$. $\mathrm{K}$ вопросу о тектономагматической модели вулкана Плоский Толбачик и его ареальных зон. Вулканизм и связанные с ним процессы. Петропавловск-Камчатский: ИВиС ДВО РАН. 2015. С. 143-145.

Гонтовая Л.И., Попруженко С.В., Низкоус И.В., Апрел$\kappa о в ~ C . E$. Верхняя мантия Камчатки: глубинная модель и связь с тектоникой // Тихоокеанская геология. 2008. № 2. С. 80-91.

Гонтовая Л.И., Хренов А.П., Степанова М.Ю., Сеню-

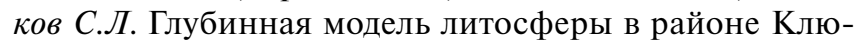
чевской группы вулканов (Камчатка) // Вулканология и сейсмология. 2004. № 3. С. 3-11.

Горбатиков А.В., Ларин Н.В., Моисеев Е.И., Беляшов $A . B$. Применение метода микросейсмического зондирования для изучения строения погребенной трубки взрыва // Докл. РАН. 2009. Т. 428. № 4. С. 526-530.

Горбатиков А.B. Способ сейсморазведки. Патент РФ № 2271554 // Бюллетень изобретений. 2006. № 7.

Горбатиков A.B., Степанова М.Ю. Результаты исследований статистических характеристик и свойств стационарности низкочастотных микросейсмических сигналов // Физика Земли. 2008. № 1. С. 57-67.
Горбатиков А.В., Степанова М.Ю. Камшилин А.Н. Специфика применения метода микросейсмического зондирования в инженерных задачах // Вопросы инженерной сейсмологии. 2008а. Т. 35. № 2. С. 25-30.

Горбатиков А.В., Степанова М.Ю., Кораблев Г.Е. Закономерности формирования микросейсмического поля под влиянием локальных геологических неоднородностей и зондирование среды с помощью микросейсм // Физика Земли. 2008б. № 7. С. 66-84.

Горбатиков A.B., Цуканов А.А. Моделирование волн Рэлея вблизи рассеивающих скоростных неоднородностей. Изучение возможностей метода микросейсмического зондирования // Физика Земли. 2011. № 4. C. 96-112.

Гордеев Е.И., Муравьев Я.Д., Самойленко С.Б., Волынеи, A.O., Мельников Д.В., Двигало В.Н. Трещинное Толбачинское извержение 2012-2013 гг. Первые результаты // Докл. РАН. 2013. Т. 452. № 5. С. 562-566.

Двигало В.Н., Федотов С.А., Чирков А.М. Вулкан Плоский Толбачик. Действующие вулканы Камчатки / Отв. ред. Федотов С.А., Масуренков Ю.П. Т. 1. М.: Наука. 1991. С. 200-213.

Добрецов Н.Л., Кулаков И.Ю., Литасов К.Д. Пути миграции магм и флюидов и составы вулканических пород Камчатки // Геология и геофизика. 2012. Т. 53. № 12. C. $1633-1661$.

Добрецов Н.Л., Кулаков И.Ю., Литасов К.Д., Кукарина $E . B$. Значение геологии, экспериментальной петрологии и сейсмотомографии для комплексной оценки субдукционных процессов // Геология и геофизика. 2015. T. 56. № 1-2. С. 21-55.

Добрецов Н.Л., Симонов В.А., Котляров А.В., Кулаков P.Ю., Карманов Н.С. Физико-химические параметры кристаллизации расплавов в промежуточных надсубдукционных камерах // Геология и геофизика. 2016. T. 57. № 7. C. 1265-1291.

Ермаков В.А, Геншафт Ю.С. Механизм извержения Северного прорыва Толбачинского дола в 1975 г. // Докл. AH CCCP. 1980. T. 255. № 5. С. 1076-1080.

Ермаков В.А., Важеевская О.А. Вулканы Острый и Плоский Толбачик // Бюл. вулк. ст. 1973. № 49. С. 43-53.

Ермаков В.А., Гонтовая Л.И., Сенюков С.Л. Тектонические условия и магматические источники нового Толбачинского трещинного извержения (п-ов Камчатка) // Геофизические процессы и биосфера. 2014. Т. 13. № 1. C. 5-33.

Ермаков В.A., Ермаков А.В. Геолого-петрологические модели извержения 1975-76 гг. на Толбачинском долу (Ключевская группа вулканов) // Геофизические исследования. М.: ИФЗ РАН. 2006. Вып. 5. С. 53-115.

Ермаков В.А., Милановский Е.Е., Таракановский А.А. Значение рифтогенеза в формировании четвертичных вулканических зон Камчатки // Вестник МГУ. Серия геологическая. 1974. № 3. С. 3-20.

Жостков Р.А., Преснов Д.А., Собисевич А.Л. Развитие метода микросейсмического зондирования // Вестник КРАУНЦ. Науки о Земле. 2015. № 2. Вып. 26. С. 11-19. 
Зубин М.И., Таракановский А.А. Тектоника и особенности поля силы тяжести района Ключевской группы вулканов. Глубинное строение, сейсмичность и современная деятельность Ключевской группы вулканов. Владивосток. 1976. С. 17-28.

Колосков А.В., Давыдова М.Ю., Ананьев В.В., Кандрин $A . A$. Толбачинский вулканический центр: состав продуктов, этапность проявления, петрологическая модель // Вулканология и сейсмология. 2017. № 4. С. 3-29.

Колосков А.В., Давыдова М.Ю., Избеков П.Э., Ананьев B.B., Кандрин A.A. Эволюция состава пород Новых Толбачинских вулканов в ходе извержения 2012-2013 гг. мантийный контроль в формате “онлайн” // Тихоокеанская геология. 2015. Т. 34. № 5. С. 19-39.

Королева Т.Ю., Яновская Т.Б., Патрушева С.С. Использование сейсмического шума для определения структуры верхней толщи Земли // Физика Земли. 2009. № 5. C. $3-14$

Кугаенко Ю.А., Салтыков В.А., Горбатиков А.В., Степанова М.Ю., Абкадыров И.Ф. Новые данные о глубинном строении Северного прорыва Большого трещинного Толбачинского извержения // Докл. РАН. 2011. Т. 441. № 4. С. 539-543.

Кугаенко Ю.А., Абубакиров И.Р., Иванова Е.И., Павлов B.M., Салтыков B.A. Толудская серия землетрясений 29.11.-7.12 2012 г., сопровождавшая начало Трещинного Толбачинского извержения. Проблемы комплексного геофизического мониторинга Дальнего Востока России. Труды V научно-технической конференции. Петропавловск-Камчатский, 27.09-03.10.2015 г. Обнинск: ГС РАН. 2015a. С. 56-60.

Кугаенко Ю.А., Салтыков В.А., Горбатиков А.В., Степанова М.Ю. Развитие модели района Узон-Гейзерной вулкано-тектонической депрессии и вулкана Кихпиныч (Камчатка) по результатам совместного анализа данных микросейсмического зондирования и локальной геодинамической активности // Физика Земли. 2015б. № 3. С. 89-101.

Кугаенко Ю.А., Титков Н.Н., Салтыков В.А., Вороnаев П.В. Анализ подготовки Трещинного Толбачинского извержения 2012-2013 гг. в параметрах сейсмичности и деформаций земной коры по данным системы комплексного мониторинга активности вулканов Камчатки // Вулканология и сейсмология. 2015в. № 4. C. $40-58$.

Кугаенко Ю.А., Салтыков В.А., Горбатиков А.В., Степанова М.Ю. Особенности глубинного строения района Северного прорыва Большого трещинного Толбачинского извержения 1975-1976 гг. по данным микросейсмического зондирования // Вулканология и сейсмология. 2013а. № 5. С. 23-39.

Кугаенко Ю.А., Фирстов П.П., Воропаев П.В., Махмудов E.P., Макаров Е.О., Коновалова А.А. Комплексная геофизическая экспедиция в район Трещинного Толбачинского извержения 2012-2013 гг. // Вестник КРАУНЦ. Науки о Земле. 2013б. № 2. Вып. 22. С. 225-231.

Магуськин М.А., Левин В.Е., Бахтиаров В.Ф. Деформации земной поверхности в районе Большого трещинного
Толбачинского извержения 1975-1976 гг. в период 1978-2000 гг. и их возможные причины // Вулканология и сейсмология. 2003. № 6. С. 55-61.

Мелекесиев И.В., Брайцева О.А., Пономарева В.В. Новый подход к определению понятия “действующий вулкан”. Геодинамика и вулканизм Курило-Камчатской островодужной системы. Петропавловск-Камчатский: ИВГиГ ДВО РАН. 2001. С. 191-203.

Мелекесиев И.В., Хренов А.П., Кожемяка Н.Н. Тектоническое положение и общий очерк вулканов Северной группы и Срединного хребта. Действующие вулканы Камчатки / Отв. ред. Федотов С.А., Масуренков Ю.П. T. 1. М.: Наука. 1991. С. 74-78.

Мороз Ю.Ф., Логинов В.А. Геоэлектрическя модель Толбачинского извержения им. 50-летия Института вулканологии и сейсмологии ДВО РАН // Вулканология и сейсмология. 2016. № 5. С. 21-34.

Новейший и современный вулканизм на территории России. М.: Наука. 2005, 604 с.

Рогожин Е.А., Горбатиков А.В., Харазова Ю.В., Степанова М.Ю., Николаев А.В. Особенности глубинного строения и геологической активности горы Эльбрус и участка ущелья Эльбрус-Тырныауз по комплексу геолого-геофизических данных // Докл. РАН. 2016. Т. 471 № 3. С. $350-353$.

Салтыков В.А., Кугаенко Ю.А., Воропаев П.В. Об аномалии сейсмического режима, предварявшей новое (2012 г.) трещинное Толбачинское извержение на Камчатке // Вестник КРАУНЦ. 2012. № 2. Вып. 20. С. 16-19.

Смирнов В.С. Особенности геоэлектрического разреза района Новых Толбачинских вулканов // Вулканология и сейсмология. 1979. № 2. С. 21-27.

Собисевич А.Л., Горбатиков А.В., Овсюченко А.Н. Глубинное строение грязевого вулкана горы Карабетова // Докл. РАН. 2008. Т. 42. № 4. С. 542-546.

Федорченко И.А., Титлинов В.С., Скачков П.П., Алексеев B.A. Электромагнитное индукционное зондирование в районе Большого трещинного Толбачинского извержения // Вулканология и сейсмология. 1980. № 2. C. $112-118$

Федотов С.A. Энергетическая классификация Курило-Камчатских землетрясений и проблема магнитуд. М.: Наука. 1972. 116 с.

Федотов С. А., Жаринов Н. А., Гонтовая Л.И. Магматическая питающая система Ключевской группы вулканов (Камчатка) по данным об ее извержениях, землетрясениях, деформациях и глубинном строении// Вулканология и сейсмология. 2010. № 1. С. 3-35.

Федотов С.А., Балеста С.Т., Двигало В.Н., Разина А.А., Флеров Г.Б., Чирков А.М. Новые Толбачинские вулканы // Действующие вулканы Камчатки. Т. 2. М.: Наука. 1991. С. 214-274.

Федотов С.А., Славина Л.Б., Сенюков С.Л., Кучай М.С. Сейсмические процессы и перемещение магм, происходившие при Большом трешинном Толбачинском извержении 1975-1976 гг. и Трещинном Толбачинском 
извержении 2012-2013 гг. // Геофизические процессы и биосфера. 2014. Т. 13. № 3. С. 5-30.

Федотов С.А., Уткин И.С., Уткина Л.И. Периферический магматический очаг базальтового вулкана Плоский Толбачик, Камчатка: деятельность, положение и глубина, размеры и их изменения по данным о расходе магм // Вулканология и сейсмология. 2011. № 6. C. $3-20$.

Флеров Г.Б., Ананьев В.В., Пономарев Г.П. Петрогенезис пород вулканов Острого и Плоского Толбачиков и соотношение вулканических проявлений базальтовой и трахибазальтовой магм на территории Толбачинского Дола (Камчатка) // Вулканология и сейсмология. 2015. № 3. C. 15-35.

Флеров Г.Б., Андреев В.Н., Будников В.А., Цюрупа А.И. Петрология продуктов извержения. Большое трещинное Толбачинское извержение / Отв. ред. С.А. Федотов. М.: Наука. 1984. Гл. VI. С. 223-284.

Цуканов А.А., Горбатиков А.В. Метод микросейсмического зондирования: влияние аномальных значений коэффициента Пуассона и оценка величины нелинейных искажений // Физика Земли. 2015. № 4. С. 94-102.

Чебров В.Н., Дрознин Д.В., Кугаенко Ю.А., Левина В.И., Сенюков С.Л., Сергеев В.А., Шевченко Ю.В., Ящук В.В. Система детальных сейсмологических наблюдений на Камчатке в 2011 г. // Вулканология и сейсмология. 2013. № 1. C. $18-40$.

Яновская Т.Б. К теории метода микросейсмического зондирования // Физика Земли. 2017. № 6. С. 18-23.

Aki K. Space and time spectra of stationary stochastic waves, with special reference to microtremors // Bull. Earthq. Res. Inst. 1957. V. 35. C. 415-456.

Albert S., Fee D., Firstov P., Makhmudov E., Izbekov P. Infrasound from the 2012-2013 Plosky Tolbachik, Kamchatka fissure eruption // J. Volcanol. Geotherm. Res. 2015. V. 307. P. 68-78.

Belousov A., Belousova M., Edwards B., Volynets A., Melnikov D. Overview of the precursors and dynamics of the 2012-13 basaltic fissure eruption of Tolbachik Volcano, Kamchatka, Russia // J. Volcanol. Geotherm. Res. 2015. 2015. V. 307. P. 22-37.

Caudron C., Taisne B., Kugaenko Yu., Saltykov V. Magma migration at the onset of the 2012-13 Tolbachik eruption revealed by Seismic Amplitude Ratio Analyses // J. Volcanol. Geotherm. Res. 2015. V. 307. P. 60-67.

Chavez-Garcia F.J., Rodriguez M., Stephenson W.R. An alternative approach to the SPAC analysis of microtremors: exploiting stationarity of noise // Bull Seism. Soc. Am. 2005. V. 95. P. 277-293.

Chouet B., De Luca G., Milina G., Dawson P., Martini M., Scarpa $R$. Shallow velocity structure of Stromboli Volcano, Italy, derived from small-aperture array measurements of Strombolian tremor //Bull.seism. Soc. Am. 1998. V. 88. P. 653-666.

Churikova T.G., Gordeychik B.N., Edwards B.R., Ponomareva V.V., Zelenin E. The Tolbachik volcanic massif: a review of the petrology, volcanology and eruption history prior to the 2012-2013 eruption // J. Volcanol. Geotherm. Res. 2015a. V. 307. P. 3-21.

Churikova T.G., Gordeychik B.N., Iwamori H., Nakamura H., Ishizuka O., Nishizawa T., Haraguchi S., Miyazaki T., Vaglarov B.S. Petrological and geochemical evolution of the Tolbachik volcanic massif, Kamchatka, Russia // J. Volcanol. Geotherm. Res. 20156. V. 307. P. 156-181.

Danilov K.B. The structure of the Onega downthrown block and adjacent geological objects according to the microseismic sounding method // Pure and Applied Geophysics. 2017. V. 174. № 7. P. 2663-2676.

Edwards B., Belousov A., Belousova M., Volynets A., Melniknov D., Chirkov S., Senyukov S., Gordeev E., Muraviev Y., Izbekov P., Demianchuk Y. Another "Great Tolbachik" Eruption? // EOS, Transactions American Geophysical Union. 2013. V. 94. № 21. P. 189-191.

Gorbatikov A.V., Montesinos F.G., Arnoso J., Stepanova M.Yu., Benavent M., Tsukanov A.A. New features in the subsurface structure model of El Hierro Island (Canaries) from lowfrequency microseismic sounding. An insight into the 2011 seismo-volcanic crisis // Surveys in Geophysic. 2013. V. 34. № 4. P. 463-489.

Ivanov I., Koulakov I., West M., Jakovlev A., Gordeev E. Magma sources beneath the Klyuchevskoy and Bezymianny volcanoes inferred from local earthquake seismic tomography // J. Volcanol. Geotherm. Res. 2016. V. 323. № 1. P. 62-71.

Kasatkina E., Koulakov I., West M., Izbekov P. Structure of magma reservoirs beneath the Redoubt volcano inferred from local earthquake tomography // J. Geophys. Res. Solid Earth. 2014. V. 119. № 6. P. 4938-4954.

Koulakov I., Abkadyrov I., Arifi N., Deev E., Droznina S., Gordeev E., Jakovlev A., Khrepy S., Kulakov R., Kugaenko Yu., Novgorodova A., Senyukov S., Shapiro N., Stupina T., West M. Three different types of plumbing systems beneath the neighboring active volcanoes of Tolbachik, Bezymianny and Klyuchevskoy in Kamchatka // J. Geophys. Res. Solid Earth. 2017. V. 122, Iss. 5, P. 3852-3874. http://dx.doi. org/10.1002/2017JB014082

Koulakov I., Gordeev E.I., Dobretsov N.L., Vernikovsky V.A., Senyukov S.L., Jakovlev A. Feeding paths of the Klucheskoy volcano group (Kamchatka) from the results of local earthquake tomography // Geophys. Res. Lett. 2011. V. 38. L09305. doi:10.1029/2011GL046957

Koulakov I., Gordeev E.I., Dobretsov N.L., Vernikovsky V.A., Senyukov S., Jakovlev A., Jaxybulatov K. Rapid changes in magma storage beneath the Klyuchevskoy group of volcanoes inferred from time-dependent seismic tomography // J. Volcanol. Geotherm. Res. 2013. V. 263. P. 75-91.

Kugaenko Yu., Titkov N., Saltykov V. Constraints on unrest in the Tolbachik volcanic zone in Kamchatka prior the 2012-13 flank fissure eruption of Plosky Tolbachik volcano from local seismicity and GPS data // J. Volcanol. Geotherm. Res. 2015. V. 307. P. 38-46.

Lees J.M., Symons N., Chubarova O.S., Gorelchik V.I., Ozerov A. Yu. Tomographic images of Klyuchevskoy Volcano P-wave velocity. Volcanism and Subduction: the Kamchatka 
region. Geophysical monograph 172 / Ed. Eichelberger J., Gordeev E. Washington: AGU. 2007. P. 293-302.

Lundgren P., Kiryukhin A., Milillo P., Samsonov S. Dike model for the 2012-2013 Tolbachik eruption constrained by satellite radar interferometry observations // J. Volcanol. Geotherm. Res. 2015. V. 307. P. 79-88.

Malagnini L., Rovelli A., Hough S.E., Seeber L. Site amplification estimates in the Garigliano Valley, Central Italy, based on dense array measurements of ambient noise // Bull. Seism. Soc. Am. 1993. V. 83. P. 1744-1755.

Nakamura Y. A method for dynamic characteristic estimation of subsurface using microtremor on the ground surface // Quarterly Report of Railway Technical Research Institute. 1989. V. 30. No 1. P. 25-33.

Nemeth K., Kereszturi G. Monogenetic volcanism: personal views and discussion // International Journal of Earth Sciences. 2015. V. 104. № 8. P. 2131-2146.

Ohori M., Nobata A., Wakamatsu K. A comparison of ESAC and FK methods of estimating phase velocity using arbitrarily shaped microtremor analysis // Bull. Seism. Soc. Am. 2002. V. 92. P. 2323-2332.

Okada $H$. Theory of efficient array observations of microtremors with special reference to the SPAC method// Exploration Geophysics. 2006. V. 37. P. 73-85.

Panou A.A., Theodulidis N., Hatzidimitriou P.M., Papazachos C.B., Stylianidis K. Ambient noise horizontal-to-vertical spectral ratio for assessing site effects in urban environments: the case of Thessaloniki city (Northern Greece) // Bull. Geol. Soc. of Greece. 2004. V. XXXVI. Proc. 10th International Congress. Thessaloniki. April 2004. P. 1467-1476.
Portnyagin M., Duggen S., Hauff F., Mironov N., Bindeman I., Thirlwall M., Hoernle K. Geochemistry of the Late Holocene rocks from the Tolbachik volcanic field, Kamchatka: towards quantitative modeling of subduction-related open magmatic systems // J. Volcanol. Geotherm. Res. 2015. V. 307. P. 133155. doi: 10.1016/j.jvolgeores.2015.08.015

Sabra K.G., Gerstoft P., Roux P., Kuperman W.A., Fehler M.C. Extracting time-domain Greens function estimates from ambient seismic noise // Geophys. Res. Lett. 2005. V. 32. L03310. Doi:10.1029/2004GL021862.

Shapiro N.M., Campillo M. Emergence of broadband Rayleigh waves from correlations of the ambient seismic noise // Geophys. Res. Lett. 2004. V. 31. L07614. Doi:10.1029/2004GL019491.

Shapiro N.M., Campillo M., Stehly L., Ritzwoller $M . H$. Highresolution surface-wave tomography from ambient seismic noise // Science. 2005. V. 307. P. 1615-1618.

Snieder R. Extracting the Green's Function from Correlation of Coda Waves: A Derivation Based on Stationary Phase // Phys. Rev. 2004. V. 69. P. 046610-1-046610-8.

Tanimoto T., Alvizuri C. Inversion of the $\mathrm{HZ}$ ratio of microseisms for S-wave velocity in the crust // Geophys. J. Int. 2006. V. 165. P. 323-335.

Volynets A., Edwards B., Melnikov D., Yakushev A., Griboedova I. Monitoring of the volcanic rock compositions during the 2012-2013 fissure eruption at Tolbachik volcano, Kamchatka // J. Volcanol. Geotherm. Res. 2015. V. 307. P. $120-132$.

Zhang S.H., Chan L.S., Xia J. The selection of field acquisition parameters for dispersion images from multichannel surface wave data //Pure. Appl. Geophys. 2004. V. 161. P. 185-201. 